\title{
Cyclin-B homologs in Saccharomyces cerevisiae function in $S$ phase and in $G_{2}$
}

\author{
Helena Richardson, ${ }^{1,2}$ Daniel J. Lew, ${ }^{1}$ Martha Henze, ${ }^{1}$ Katsunori Sugimoto, ${ }^{1,3}$ and Steven I. Reed ${ }^{1,4}$ \\ ${ }^{1}$ Department of Molecular Biology, The Scripps Research Institute, La Jolla, California 92037 USA; ${ }^{2}$ Department of \\ Biochemistry, University of Adelaide, Adelaide, South Australia 5001
}

\begin{abstract}
We have cloned four cyclin-B homologs from Saccharomyces cerevisiae, CLB1-CLB4, using the polymerase chain reaction and low stringency hybridization approaches. These genes form two classes based on sequence relatedness: $C L B 1$ and $C L B 2$ show highest homology to the Schizosaccharomyces pombe cyclin-B homolog cdc13 involved in the initiation of mitosis, whereas $C L B 3$ and $C L B 4$ are more highly related to the $S$. pombe cyclin-B homolog cig1, which appears to play a role in $\mathrm{G}_{1}$ or $\mathrm{S}$ phase. $C L B 1$ and $C L B 2 \mathrm{mRNA}$ levels peak late in the cell cycle, whereas $C L B 3$ and $C L B 4$ are expressed earlier in the cell cycle but peak later than the $\mathrm{G}_{1}$-specific cyclin, $C L N 1$. Analysis of null mutations suggested that the $C L B$ genes exhibit some degree of redundancy, but $c l b 1,2$ and $c l b 2,3$ cells were inviable. Using $c l b 1,2,3,4$ cells rescued by conditional overproduction of $C L B 1$, we showed that the $C L B$ genes perform an essential role at the $G_{2} / M$-phase transition, and also a role in $S$ phase. $C L B$ genes also appear to share a role in the assembly and maintenance of the mitotic spindle. Taken together, these analyses suggest that $C L B 1$ and $C L B 2$ are crucial for mitotic induction, whereas $C L B 3$ and $C L B 4$ might participate additionally in DNA replication and spindle assembly.
\end{abstract}

[Key Words: Yeast; cyclin-B homologs; S-phase; mitosis; Cdc28 kinase]

Received June 8, 1992; revised version accepted August 11, 1992.

The eukaryotic cell cycle is highly conserved in both mechanism and components from yeast to man (for recent reviews, see Cross et al. 1989; Murray and Kirschner 1989a; Lewin 1990; Nurse 1990; Pines and Hunter 1990a; Maller 1991; Reed 1991). Studies carried out in the budding yeast Saccharomyces cerevisiae and the fission yeast Schizosaccharomyces pombe have revealed that a $34-\mathrm{kD}$ serine-threonine protein kinase, known as Cdc28 or cdc2, plays a critical role in at least two key regulatory events. The first is at a point late in $G_{1}$ known as START, at which environmental factors, such as nutrient availability and the presence of mating pheromones, act to determine whether a cell will enter the cell cycle (Hartwell et al. 1974; Nurse and Bissett 1981). Second, the $\mathrm{Cdc} 28 / \mathrm{cdc} 2$ protein kinase functions at the initiation of mitosis at a point late in $\mathrm{G}_{2}$ (Nurse and Bissett 1981; Piggott et al. 1982; Reed and Wittenberg 1990; Surana et al. 1991). Studies in Xenopus have revealed that Cdc28/cdc2 is an essential component of a factor [M-phase-promoting factor (MPF)] required for the $\mathrm{G}_{2}$ - to M-phase transition (for review, see Hunt 1989; Maller 1991). Furthermore, recent studies in mammalian cells have provided functional evidence that $\mathrm{Cdc} 28 / \mathrm{cdc} 2$ is required for the initiation of mitosis (Riabowol et al. 1989; Th'ng et al. 1990), and a newly discovered cdc2like kinase [cdk2 (Elledge and Spottswood 1991; Ni-

\footnotetext{
${ }^{3}$ Present address: Department of Molecular Biology, Nagoya University, Nagoya 464-01, Japan.

${ }^{4}$ Corresponding author.
}

nomiya-Tsuji et al. 1991; Paris et al. 1991; Tsai et al. 1991)] is required for the initiation of $S$ phase (Fang and Newport 1991).

In its active form, the Cdc28/cdc2 protein kinase is a multimeric complex with at least one other protein of 45-60 kD, known as cyclin (for review, see Hunt 1989; Murray and Kirschner 1989a; Maller 1991; Reed 1991; Xiong and Beach 1991; Lew and Reed 1992). Cyclins were initially discovered in the oocytes and embryos of marine invertebrates, as proteins that peaked in abundance just before the onset of mitosis and were then rapidly degraded during mitosis (Evans et al. 1983; Hunt et al. 1992). These "mitotic cyclins" are activators of $\mathrm{Cdc} 28 / \mathrm{cdc} 2$ for the $\mathrm{G}_{2}$ - to M-phase transition (for review, see Hunt 1989; Murray and Kirschner 1989a; Nurse 1990; Maller 1991|. Mitotic cyclins have been divided into two classes, A-type and B-type, on the basis of sequence relatedness; but they also appear to differ in their kinetics of accumulation, intracellular distribution, and association with different forms of $\mathrm{Cdc} 28 / \mathrm{cdc} 2$ (Minshull et al. 1990; Pines and Hunter 1990a,b; Hunt et al. 1992). Cyclin A and B both appear to be capable of promoting entry into mitosis when assayed in the Xenopus oocyte system (Swenson et al. 1986; Minshull et al. 1989; Murray and Kirschner 1989b; Murray et al. 1989); however these cyclins do not perform redundant roles in Drosophila (Lehner and O'Farrell 1990). In somatic animal cells, cyclin A plays a role at the initiation of $S$ phase (Girard et al. 1991; Pagano et al. 1992).

Another group of cyclins has been defined by three 
genes (CLN1,CLN2, and CLN3) in the budding yeast $S$. cerevisiae (Sudbery et al. 1980; Cross 1988; Nash et al. 1988; Hadwiger et al. 1989). These " $\mathrm{G}_{1}$ cyclins" are rate limiting for the START control point in $\mathrm{G}_{1}$ (Richardson et al. 1989; Cross 1990). The $G_{1}$ cyclins associate with Cdc28/cdc2 late in $G_{1}$, and this is presumed to result in the activation of the kinase for its essential START function (Wittenberg et al. 1990; Reed 1991). $G_{1}$ cyclins may be present in animal cells, although the candidates that have been identified are structurally diverged from the yeast $G_{1}$ cyclins (for review, see Xiong and Beach 1991; Lew and Reed 1992).

Genetic analysis of the fission yeast $S$. pombe has identified a cyclin-B homolog, $c d c 13$, that is required for entry into mitosis (Booher and Beach 1987; Hagan et al. 1988). Because classical genetic analysis of $S$. cerevisiae had not revealed any cyclin-like genes required for mitosis, we sought to identify these genes by using degenerate oligonucleotides and the polymerase chain reaction (PCR) and by low stringency hybridization. As reported previously, we identified four cyclin-B homologs from $S$. cerevisiae, which we named SCB1-SCB4 (Ghiara et al. 1991). Surana et al. (1991) have also isolated four cyclin-B homologs from $S$. cerevisiae, named $C L B 1-C L B 4$, by rescue of a $c d c 28-1 \mathrm{~N}$ mutant and by PCR. In our last report (Ghiara et al. 1991), we characterized the first of these cyclin-B homologs, SCB1 (or CLB1), and showed that it has properties consistent with a role in the $G_{2}$ - to $M$-phase transition. In this report we investigate the function of the other cyclin-B homologs in $S$. cerevisiae and show that these cyclins play a role in the $G_{2}$ phase and also the $S$ phase of the cell cycle. This latter role for B-type cyclins may be analagous to the S-phase function inferred for cyclin A in animal cells (Girard et al. 1991; Pagano et al. 1992).

\section{Results}

\section{Isolation of four cyclin-B homologs from S. cerevisiae}

We (Ghiara et al. 1991) and others (Surana et al. 1991) reported previously the existence of at least four cyclin-B homologs in S. cerevisiae. Surana et al. (1991) described the sequence of $C L B 1$ and $C L B 2$ and provided partial amino acid sequence for $C L B 3$ and $C L B 4$. Using both PCR and low stringency hybridization approaches (Materials and methods), we had cloned the same four genes. The complete DNA sequences and predicted translation products of CLB3 and CLB4 are presented in Figure 1.

As reported previously (Surana et al. 1991), the CLB genes are related most closely to $S$. pombe cyclin-B homologs $c d c 13$ (Booher and Beach 1988; Hagan et al. 1988) and cig1 (Bueno et al. 1991). Clb1 and Clb2 are closely related to each other and show the highest homology to cdc13 (Table 1). Clb3 and Clb4 are also related to each other, but they show the highest homology with cig1 (Table 1; Fig. 2). cdc13 has been shown to be required for the $\mathrm{G}_{2}$ - to $\mathrm{M}$-phase transition (Booher and Beach 1987; Hagan et al. 1988), whereas the cig1 gene appears to play a role in the initiation or execution of $S$ phase (Bueno et al. 1991).
Glotzer et al. (1991) have identified a sequence present at the amino terminus of sea urchin cyclin $B$ that is required for cyclin degradation. This sequence, known as the mitotic destruction box and having the consensus sequence of R-ALGD(NEV)I-N, is highly conserved in cyclin-B and cyclin-A sequences. All four of the Clb proteins have a sequence at the amino terminus that fits this consensus (Table 2). Interestingly, the presumptive destruction box of $\mathrm{Clb3}$ has an arginine at the sixth position. Glotzer et al. (1991) have observed that in all known cyclin-B sequences there is always an asparagine, aspartic acid, or glutamic acid at position six, whereas cyclin-A sequences have a valine residue at this position. Thus, Clb3 does not fit either the cyclin-B or cyclin-A consensus at this position. It has also been noted that cyclin-A and cyclin-B sequences have a lysine-rich region following the destruction box laverage of 6 lysine residues in 46 amino acids following the destruction box), which may constitute acceptor sites for ubiquitin conjugation (Glotzer et al. 1991). All four Clb proteins have 4 or 5 lysine residues in a region of 50 amino acids following the destruction box (Fig. 2, data not shown).

\section{CLB3 and CLB4 $m$ RNAs accumulate earlier} in the cell cycle than do CLB1 and CLB2 mRNAs

We have shown previously that $C L B 1 \mathrm{mRNA}$ is periodic during the cell cycle, peaking at a late time consistent with mitotic function, and that this results in a corresponding increase in Clb1 protein (Ghiara et al. 1991). To investigate the accumulation of mRNAs for CLB2, $C L B 3$, and CLB4 during the cell cycle, Northern blot analysis with radiolabeled probes was performed on RNA samples prepared from synchronized cells. Figure 3 shows the results from this analysis compared with CLB1, CLN1, and SWI5 mRNAs. CLN1 mRNA peaks late in $G_{1}$ (Wittenberg et al. 1990), whereas SWI5 and CLB1 mRNAs peak late in $\mathrm{G}_{2}$ (Nasmyth et al. 1987; Ghiara et al. 1991). As for CLB1, the mRNAs for the other three $C L B$ genes varied in abundance through the cell cycle. However, the cell cycle accumulation of mRNA from the four $C L B$ genes was clearly not identical. CLB2 mRNA accumulation was similar to SWI5 and CLB1 mRNAs [consistent with the results of Surana et al. (1991)], peaking late in the cell cycle coincident with the peak in large budded cells. This corresponds to cells late in $\mathrm{G}_{2}$ or in mitosis. Surprisingly, CLB3 and CLB4 mRNAs began to accumulate late in $G_{1}$ at the same time as CLN1 mRNA and reached a peak in abundance at the time when small budded cells were maximal (in $S$ phase, after the peak of CLN1 mRNA accumulation; Fig. 3). In addition, there appears to be a significant basal level of these species early in $\mathrm{G}_{1}$. Thus, $C L B 1$ and $C L B 2$ mRNAs accumulate at a time that is consistent with a role for these proteins at the $\mathrm{G}_{2} / \mathrm{M}$ phase, whereas $C L B 3$ and $C L B 4$ mRNAs accumulate earlier in the cell cycle, raising the possibility of a role in $S$ phase.

\section{Phenotype of null mutations in the CLB genes}

To investigate the functions of the CLB gene products, 
A

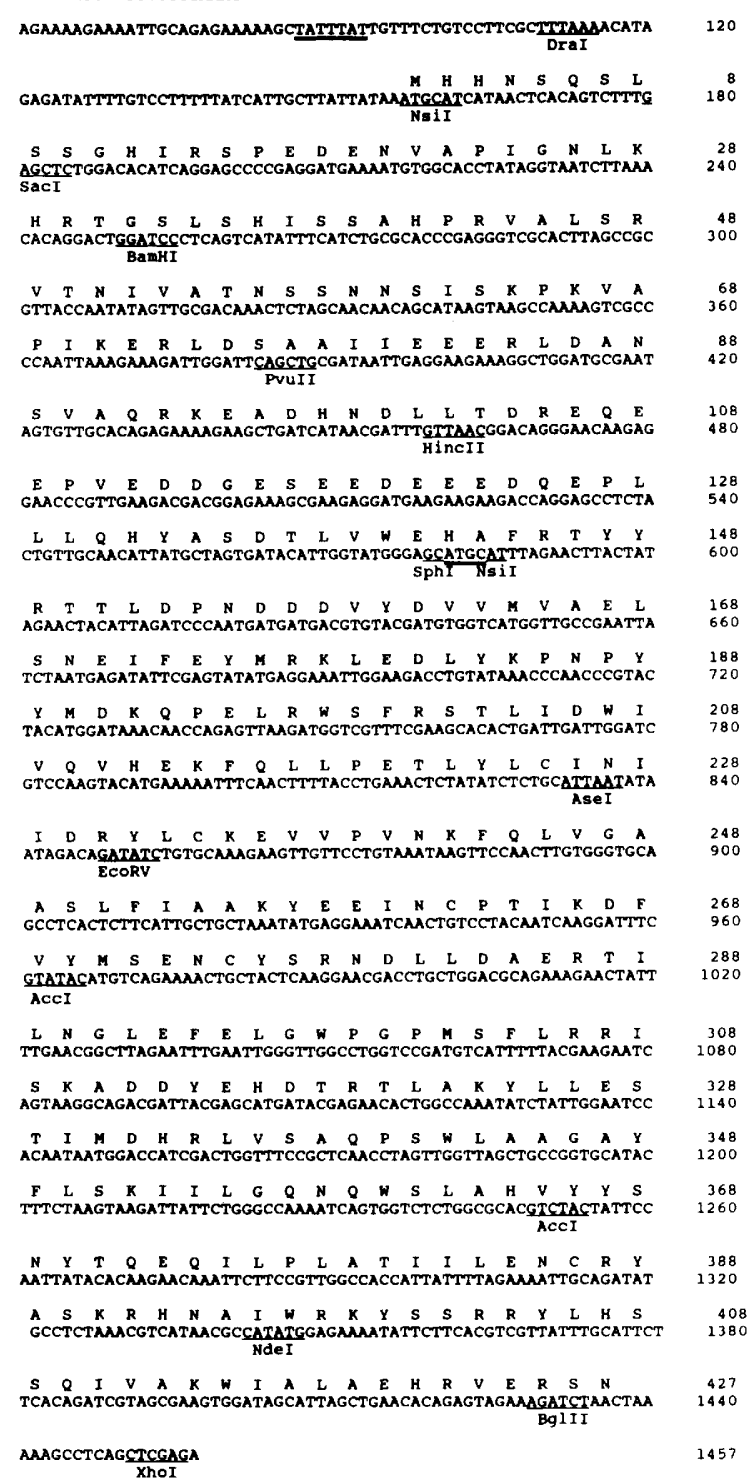

Figure 1. Sequence of $C L B 3$ and $C L B 4$. The DNA sequences and the predicted amino acid sequences of $C L B 3(A)$ and $C L B 4(B)$ are shown with relevant restriction sites and features marked.
B

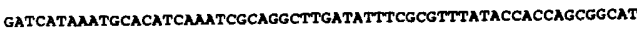
TAGTGACMATTAMATTACGACATGACCCATGTGGTTAaGCACTCTMATAGGAMaGGTAG TCTCAMACMATGTGTTGCCTTCATATCCATGAMGACGACCATTCATTMATACTACTGGTG AACCATTCATAGATCCGMCATTAGTGTACCGGAATGACCTGGMACCGTACTTTTCTTGA ATCCTGGGATGTCTTGGTATGGGACTGTTACCGGGGGTGGATTGTCTCTAGACAGCTTGG TAGATATTCCACCAGGCCTGAACCACATATAATCAMAGTTCTCGGAGGCTCGAMTTTG TTGTATTTTTGAMATGTGGTTCTAAMATAGCAGMMATATACGCAGCGGCCTTGGTAATTG CTTCACGTT GTTGACTTACGTTCAAGATATCACTCATCTTTTAAGTTTATTCGGAGTTTC TCATGTGTTCTAGAAGATTAGCAAGATTATCCTAMGTTATGCCTGCCCTATCTGCCCTC TGCTTCGAGATTTTCCTTTTCTTTGCGCTTTGTAMACACTGAAACAMAAACAMAACAAT GGAAACATCAGAMAGATATTTATTTATTGTGGCCGCATAMAGTTTTAATTCTTTGATAMT TAACGTCGTATTTGGGAAACTGCTTACTATACCGGATACTAGGCTGCCCTGATCAMACAA

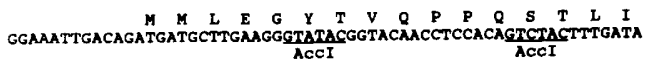

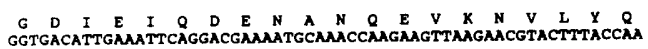

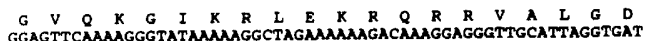

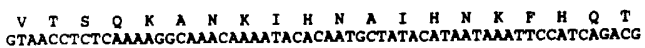
$\underset{\text { AAGAACAATTTTGAATTAGAGAACATACGCTCATCGGCCTTGGTAMAMGAACAACAACGA }}{\mathbb{N}}$ $\underset{G A C G T A A G G C A T G A G A T A G C G A C T A T T T T T T A M T T G A T A G T T C T G A G G G T C T T C T A C T}{D}$ $\underset{\text { AATGACGAACAAGTTAATGAAGATGCTATTGATGATTTGTTAMGTCGAMGAGTAAATGAT }}{D}$ CAGCAGATTCAAGCCGATGMGGTGATGAMGATTTCGATGGAGMATGCAMGATGTCATT $\underset{\text { GAGGAGGATGTTGATAGTCAAATTGAMCCACTATCACCMATAMACAACGATGMATTCAG }}{E}$ GAAGAGGATGTTGATAGTCAAATTGAACCACTATCACCAATAAACANCGATEAMH I

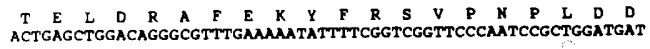

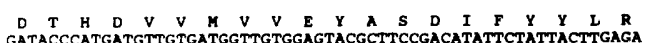

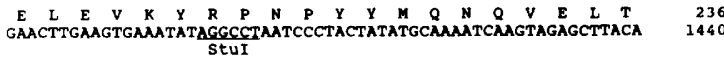

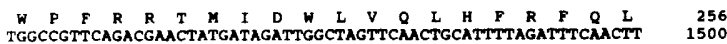
$\underset{\text { TTACCAGAAACGCTATACCTGACGATTAATATAGTGGATAGATTTCTGTCAMAGAAGACC }}{\mathrm{L}} \underset{1560}{\mathrm{P}}$

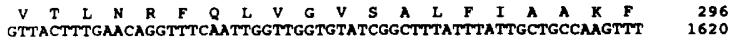

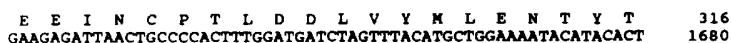

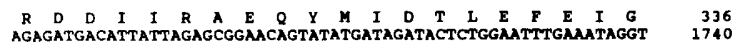

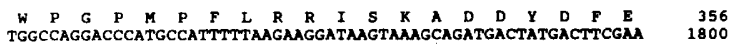

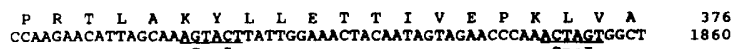
Scar

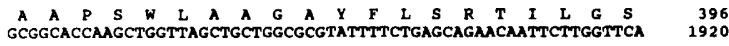

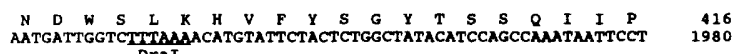

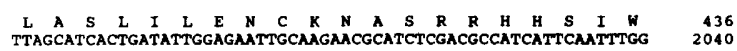

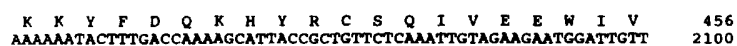

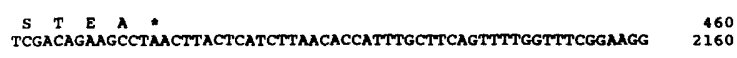
ATCATATTTCATTTATTCAGGTAGMagataTATATCATATtaCACACACACACACACACA 2220

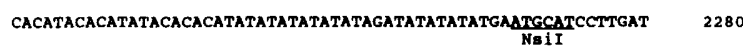
CCGTTTCAGTT 0

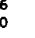
然

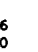
(a)

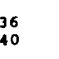
然 : (1)

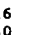
然

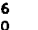

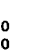

220


Table 1. Comparison of S. cerevisiae Clb proteins to other cyclins

\begin{tabular}{|c|c|c|c|c|c|c|c|c|c|c|c|c|c|}
\hline & \multicolumn{3}{|c|}{ Clb proteins $(\%)$} & \multicolumn{10}{|c|}{ Cyclins $(\%)^{a}$} \\
\hline & $\mathrm{Clb} 2$ & Clb3 & Clb4 & $\operatorname{cdc} 13$ & cigl & $\mathrm{HsBl}$ & HsA & $\mathrm{HsC}$ & $\mathrm{HsD}$ & HsE & $C \ln 1$ & $C \ln 3$ & puc1 \\
\hline Clb1 & 78 & 43.6 & 40.7 & 51.6 & 39.9 & 37 & 30.8 & 17.2 & 23.1 & 24.9 & 17.9 & 20.5 & 20.9 \\
\hline $\mathrm{Clb} 2$ & - & 42.5 & 39.9 & 51.6 & 41.4 & 38.5 & 33.3 & 16.1 & 23.4 & 28.2 & 19 & 24.9 & 22.3 \\
\hline Clb3 & - & - & 62.3 & 43.5 & 46.4 & 36.2 & 29.7 & 16.7 & 23.2 & 25.7 & 21.4 & 19.2 & 25 \\
\hline Clb4 & - & - & - & 43.1 & 45.3 & 36.2 & 30.4 & 17 & 18.5 & 21.7 & 17.4 & 20.7 & 22.8 \\
\hline
\end{tabular}

Sequences were aligned using the GAP program (Needleman and Wunsch 1970), with a GAP weight of 3.0 and a GAP length of 0.1. A region of 276 residues at the carboxyl terminus of each cyclin containing the cyclin box was used for the comparisons. Scores indicate percent identical residues within this region.

${ }^{2}$ Sources of cyclin sequences: cdcl3 (Booher and Beach 1988); cig1 (Bueno et al. 1991); HsBl (Pines and Hunter 1989); HsA (Wang et al. 1990); HsC, HsD, HsE (Lew et al. 1991); Cln1 (Hadwiger et al. 1989); Cln3 (Cross 1988); puc1 (Forsburg and Nurse 1991).

ble, $c l b 3,4$ and $c l b 1,3,4$ cells were slightly enlarged (Fig. $4 \mathrm{C}, \mathrm{D})$. The fact that $c l b 1,3,4$ cells were viable indicates that $\mathrm{Clb} 2$ can perform all essential $\mathrm{Clb}$ functions, suggesting that $\mathrm{Clb} 2$ is the dominant cyclin-B homolog in the cell during mitotic growth. The fact that mutation of $c l b 4$ did not affect the viability of any other $c l b$ mutant combination suggests that Clb4 is the cyclin-B homolog of least import in the cell during mitotic growth.

Viable $\mathrm{clb}$ combinations were analyzed by flow cytometry to determine whether they caused any perturbation in cell cycle distribution. Homozygous diploid strains were used because diploid cells contain twice as much
DNA as haploids, and clearer results can therefore be obtained. Flow cytometric analysis of propidium iodidestained $c l b 2$ cells revealed that there was a dramatic increase in cells with a $4 \mathrm{~N}$ DNA content, consistent with a delay at the $\mathrm{G}_{2}$ - to $\mathrm{M}$-phase transition (Fig. 5B). In contrast, $c l b 3,4$ or $c l b 1,3,4$ cells did not exhibit any obvious perturbation of the cell cycle distribution in exponentially growing cultures (Fig. 5C,D).

Analysis of viable $c l b$ deletion strains suggested that $C L B$ genes share at least one essential role in the cell cycle, with $\mathrm{Clb} 2$ making the greatest contribution and Clb4 the smallest. However, it is not clear from these
Figure 2. Alignment of the $C L B 3$ and CLB4 amino acid sequences with $S$. pombe cig1. Identical amino acids between $\mathrm{Clb} 3$ and $\mathrm{Clb} 4$ are indicated by vertical lines. Conservative substitutions are indicated by two dots. cig1, a B-type cyclin form $S$. pombe with $\mathrm{G}_{1}$ - or S-phase functions (Bueno et al. 1991), is also compared.

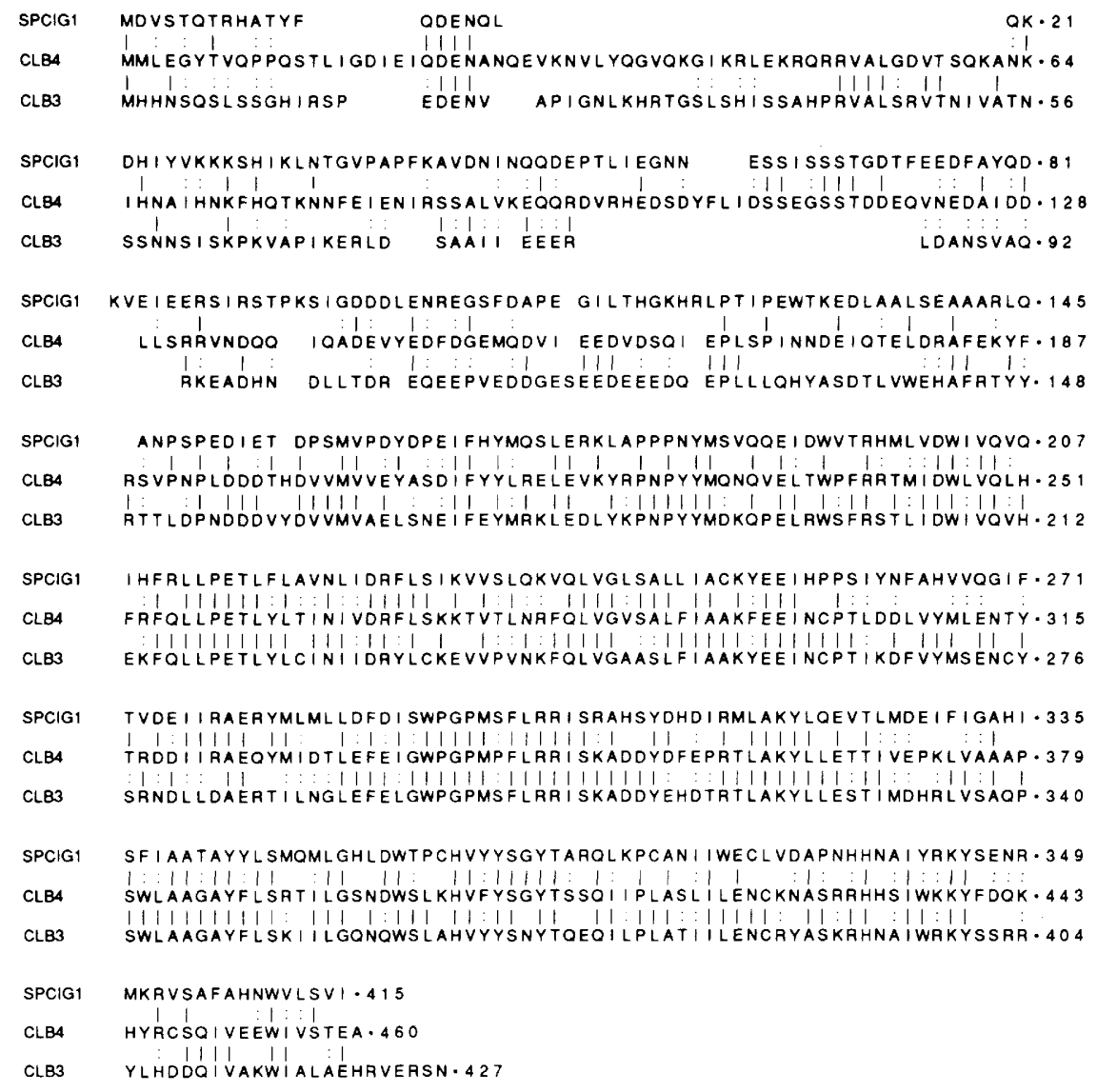


Table 2. Clb destruction box sequences

\begin{tabular}{|c|c|c|c|c|c|c|c|c|c|c|c|}
\hline & & & 1 & 2 & 3 & 4 & 5 & 6 & 7 & 8 & 9 \\
\hline Destruction box consensus & $\begin{array}{l}\text { cyclin B } \\
\text { cyclin A }\end{array}$ & & $\mathrm{R}$ & $\mathrm{X}$ & A & $\mathrm{L}$ & G & $\begin{array}{c}\text { DNE } \\
\mathrm{V}\end{array}$ & I & $\mathrm{X}$ & $\mathrm{N}$ \\
\hline Clbl & & 35 & $\mathrm{R}$ & $\mathrm{T}$ & I & $\mathrm{L}$ & G & $\mathrm{N}$ & $\mathrm{V}$ & $\mathrm{T}$ & $\mathbf{N}$ \\
\hline Clb2 & & 25 & $\mathrm{R}$ & $\mathrm{L}$ & A & $\mathrm{L}$ & $\mathrm{N}$ & $\mathrm{N}$ & $\mathrm{V}$ & $\mathrm{T}$ & $\mathrm{N}$ \\
\hline Clb3 & & 51 & $\mathbf{R}$ & $\mathrm{V}$ & A & $\mathbf{L}$ & $\mathrm{S}$ & $\mathrm{R}$ & $\mathrm{V}$ & $\mathrm{T}$ & $\mathrm{N}$ \\
\hline Clb4 & & 43 & $\mathrm{R}$ & $\mathrm{V}$ & A & $\mathbf{L}$ & G & $\mathrm{D}$ & $\mathrm{V}$ & $\mathrm{T}$ & $\mathrm{S}$ \\
\hline
\end{tabular}

experiments whether the different $C L B$ genes normally perform overlapping or distinct functions: It is possible (for example) that $\mathrm{Clb3}$ and Clb4 normally perform a specialized function in $\mathrm{S}$ phase but that in their absence Clb1 and Clb2 can substitute, so that clb3,4 cells do not display an obvious phenotype.
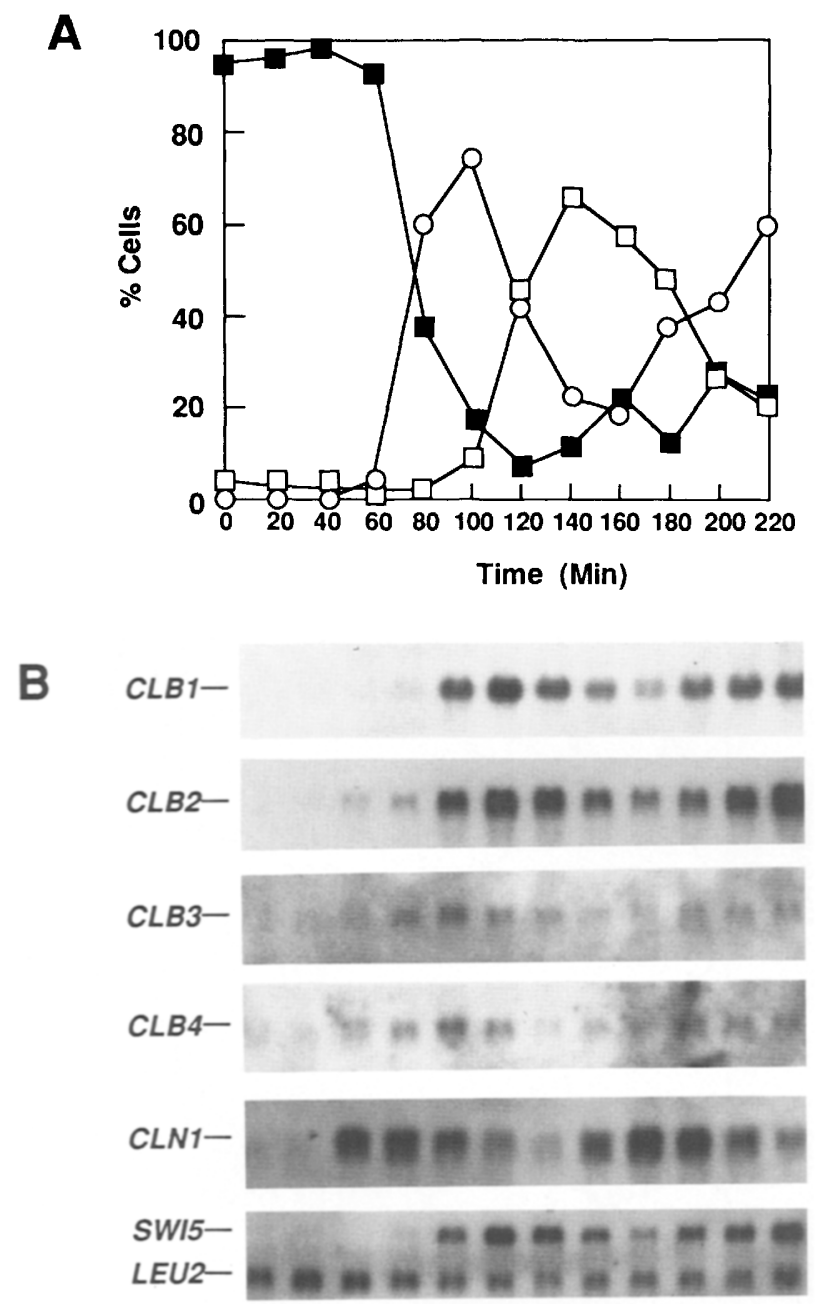

Figure 3. Timing of expression of $C L B$ mRNAs during the cell cycle. $(A)$ Cells were synchronized by mating pheromone arrest/ release as described by Ghiara et al. (1991). (四 Unbudded cells $\left(G_{1}\right) ;(O)$ cells with small buds (S phase); $(\square)$ cells with large buds $\left(G_{2} / M\right.$ phase). (B) Parallel Northern blot analyses were performed on RNA samples prepared at the indicated times following release from pheromone arrest using probes specific for the Clb1, Clb2, Clb3, Clb4, Cln1, Swi5, and Leu2 mRNAs.

\section{Conditional removal of $\mathrm{Clb}$ function}

The $G_{2} / M$ delay seen in clb2 cells (Fig. 5B) suggested that these cyclins play a role in $G_{2} / M$ phase, which is consistent with previous studies with cyclin $\mathrm{B}$ in other systems (Booher and Beach 1987, 1988; Hagan et al. 1988; Murray and Kirschner 1989b). To investigate the
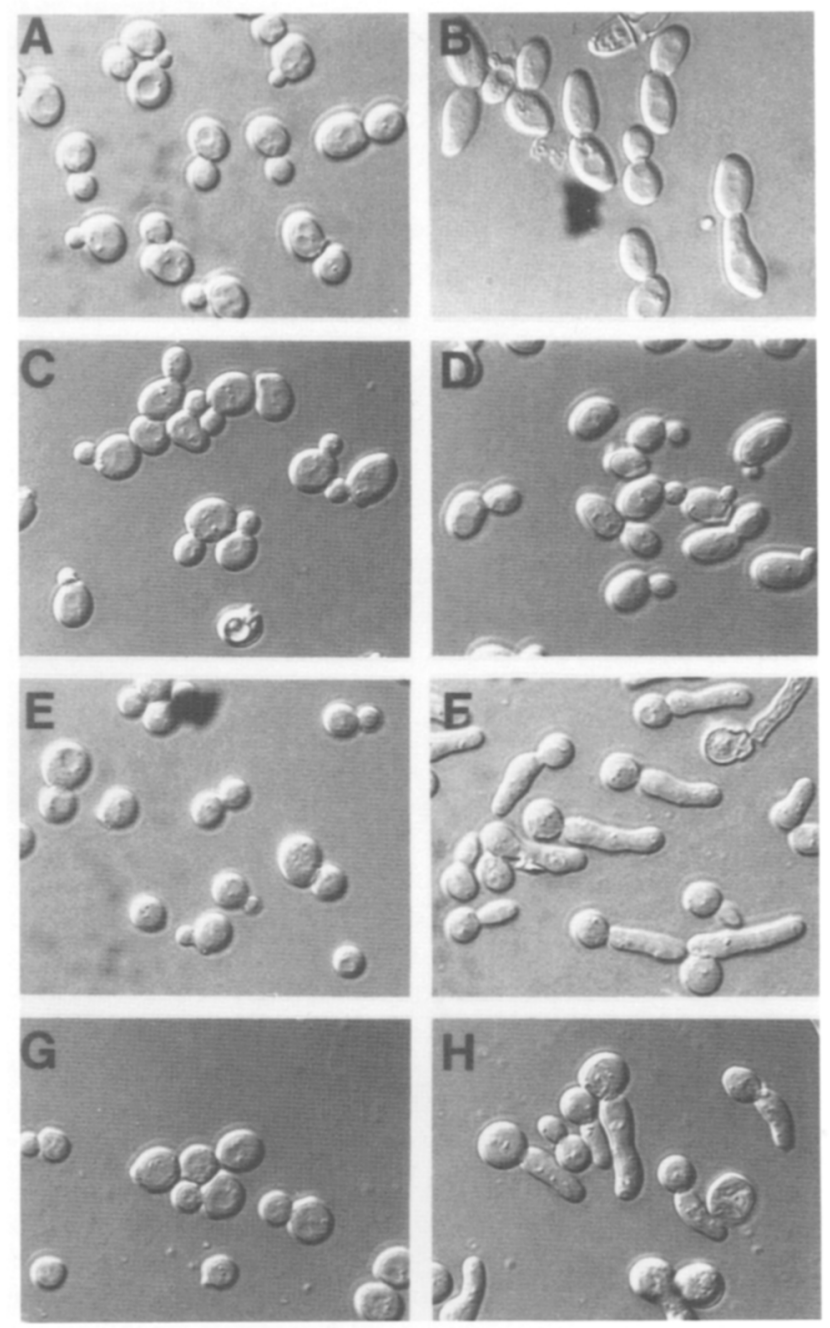

Figure 4. Morphology of $c l b$ mutant strains. Differential interference contrast microscopy was performed on wild-type $(A)$; clb2 $(B) ; c l b 3,4(C) ; c l b 1,3,4(D) ; c l b 1,2,3$ GAL1::CLB1 growing on YEPGal $(E) ; c l b 1,2,3$ GAL1::CLB1 after addition of glucose for $2 \mathrm{hr}(F)$; clb1,2,3 GAL1::CLB1 growing on YEPGal (G); and clb1,2,3,4 GAL1::CLB1 after the addition of glucose for $2 \mathrm{hr}(H)$. 
Table 3. Phenotypes of clb null mutants

\begin{tabular}{ll}
\hline Genotype & Phenotype \\
\hline clb1 & viable \\
$c l b 2$ & viable \\
$c l b 3$ & viable \\
$c l b 4$ & viable \\
$c l b 1,2$ & inviable \\
$c l b 1,3$ & viable \\
$c l b 1,4$ & viable \\
$c l b 2,3$ & inviable \\
$c l b 2,4$ & viable \\
$c l b 3,4$ & viable \\
$c l b 1,2,3$ & inviable \\
$c l b 1,2,4$ & inviable \\
$c l b 1,3,4$ & viable \\
$c l b 2,3,4$ & inviable \\
$c l b 1,2,3,4$ & inviable \\
\hline
\end{tabular}

essential roles of $\mathrm{Clb}$ proteins directly, it was necessary to construct a strain in which $C L B$ function could be conditionally controlled. To achieve conditional expression of Clb protein, the GAL1 (galactokinase) promoter, which is induced by galactose but repressed by glucose, was used. A chimeric gene was constructed composed of the GAL1 promoter fused to the coding region of CLB1 (Ghiara et al. 1991). This gene was used to rescue cells bearing all of the otherwise lethal clb combinations when grown on galactose-based media (for strain constructions, see Materials and methods). The viability of the clb1,2,3,4 GAL1::CLB1 strain demonstrates that, when overexpressed, $\mathrm{Clbl}$ is able to perform all essential $\mathrm{Clb}$ functions.

Homozygous diploid clb1,2 GAL1::CLB1, clb1,2,3 GAL1::CLB1, and $c l b 1,2,3,4$ GAL1::CLB1 strains were constructed to assess the consequences of removing $\mathrm{Clb}$ function incrementally. Cells were grown in galactose liquid medium, and CLB1 expression was terminated by the addition of glucose to $2 \%$. Samples were taken at various times and cells were fixed for counting, microscopic analysis, and analysis of DNA content by flow cytometry after staining nuclear DNA with propidium iodide (Fig. 6). Consistent with the results of Surana et al. (1991) with germinating spores, the $c l b 1,2$ mutant cells did not arrest on the first cell cycle and the cell number increased slowly through the 3 -hr time course (Fig. 6A). Nevertheless, it is clear from the flow cytometric analysis, and the accumulation of budded cells at the $3-\mathrm{hr}$ point, that loss of function of $c l b 1$ and $c l b 2$ causes the majority of cells to delay in $\mathrm{G}_{2}$ (Fig. $6 \mathrm{~B}, \mathrm{C}$ ). On the other hand, within $2 \mathrm{hr}$ after the addition of glucose to the culture, cell proliferation ceased completely for the $c l b 1,2,3$ and $c l b 1,2,3,4$ strains (Fig. 6A). Examination of the DNA content of these cells $2 \mathrm{hr}$ after the addition of glucose showed that while most of the $c l b 1,2,3$ cells arrested in $\mathrm{G}_{2}$, the clb1,2,3,4 cells almost all contained less DNA, indicating that the cells had not completed $S$ phase (Fig. 6C; arrows indicate fluorescence corresponding to $2 \mathrm{~N}$ and $4 \mathrm{~N}$ DNA content at the beginning of the experiment, representing cells in $G_{1}$ or $G_{2} / M$, respectively|. Because DNA replication is normally completed rapidly once cells bud ( $\sim 20$ min under these growth conditions; data not shown), these data suggest an impairment of some aspect of DNA replication in the clb1,2,3,4 mutants. It is difficult to assess population DNA content at the 3-hr point, because as arrested mutant cells enlarge, the contributions of autofluorescence and mitochondrial DNA tend to skew populations to higher fluorescence. Hence, the DNA content of mutant populations at $3 \mathrm{hr}$ (and, to a lesser degree, at $2 \mathrm{hr}$ ) is likely to be overestimated. These problems prevent a clear conclusion from this experiment regarding whether the clb1,2,3,4 cells eventually complete DNA replication or remain arrested in $\mathrm{S}$ phase. Nonetheless, this experiment suggests that $\mathrm{Clb}$ function is required both for mitosis and $\mathrm{S}$ phase. The difference between the $c l b 1,2,3$ cells and the $c l b 1,2,3,4$ cells (the contribution of Clb4) suggests that a moderately high level of Clb function is required to perform mitosis successfully, whereas a low level of $\mathrm{Clb}$ function is sufficient for DNA replication.

\section{Clb function is required during $S$ phase}

In flow cytometric analyses of several of the time points in the experiment described in Figure 6 and similar experiments, it appeared that cells were accumulating in a distinct S-phase peak, rather than arresting at the beginning of, or randomly throughout, S phase (e.g., Fig. 6D, 1

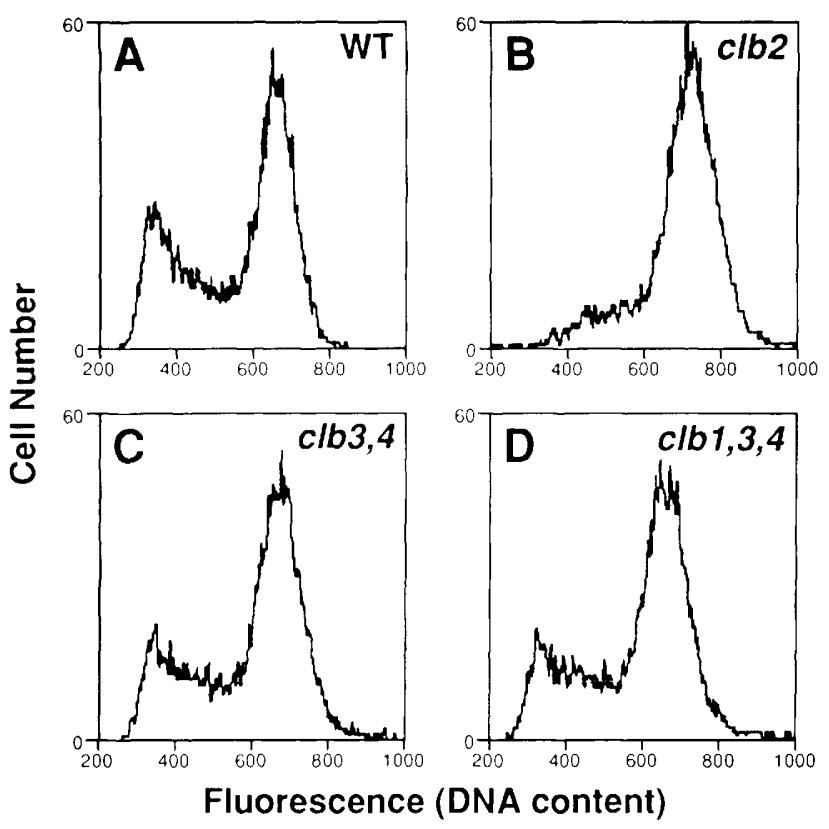

Figure 5. Flow cytometric analysis of viable clb disruption mutants. Homozygous diploid strains were used. Fluorescence measures DNA content, as analyzed by staining with propidium iodide. The left peak in each distribution corresponds to $2 \mathrm{~N}$ DNA content $\left(\mathrm{G}_{1}\right.$ cells); the right peak corresponds to $4 \mathrm{~N}$ DNA content $\left(\mathrm{G}_{2} / \mathrm{M}\right.$ cells). (A) Wild-type; $(B) \mathrm{clb2} ;(C) \mathrm{clb3}, 4 ;(D)$ $c l b 1,3,4$. 
A
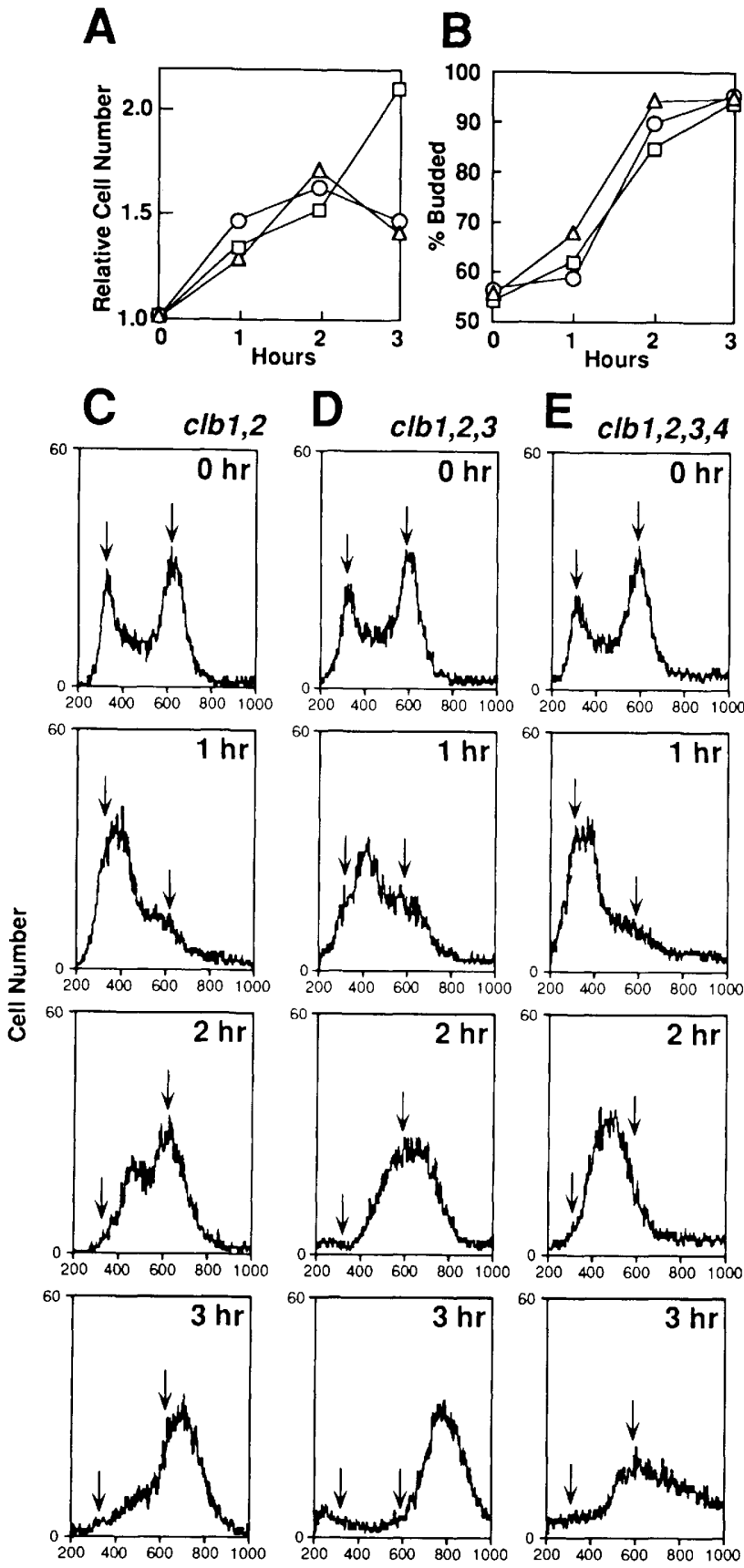

Fluorescence (DNA Content)

Figure 6. Flow cytometric analysis of lethal $\mathrm{clb}$ disruption mutants upon loss of the rescuing Clbl. (A) Analysis of cell number increase after termination of $\mathrm{Clb}$ synthesis by addition of glucose. Samples were analyzed at $0,1,2$, and $3 \mathrm{hr}$. Strains were homozygous diploids as follows: $(\square)$ clb1,2 GAL1::CLB1; (O) clb1,2,3 GAL1::CLB1; $(\triangle)$ clb1,2,3,4 GAL1::CLB1. (B) Analysis of the percentage of budded cells after termination of $\mathrm{Clb}$ synthesis. Symbols are as in $A,(C-E)$ Flow cytometric analysis of mutants after termination of $\mathrm{Clb}$ synthesis. $(C)$ clb1,2 GAL1::CLB1; (D) clb1,2,3 GAL1::CLB1; $(E)$ clb1,2,3,4 $G A L 1:: C L B 1$. Arrows indicate the positions of the $2 \mathrm{~N} / \mathrm{G}_{1}$ cells, left $)$ and $4 \mathrm{~N}\left(\mathrm{G}_{2} / \mathrm{M}\right.$ cells, right $)$ peaks for reference. Times are indicated beginning from the time of glucose addition. hr, or Fig. $6 \mathrm{E}, 2 \mathrm{hr}$. This suggested that cells lacking $\mathrm{Clb}$ proteins might be able to begin DNA replication but then might encounter a restriction at some specific point in $\mathrm{S}$ phase. To obtain more precise data germane to this issue, we selected a synchronous population of $c l b 1,2,3,4$ cells in $G_{1}$ and observed their progress through the cell cycle (Fig. 7B). We made the assumption, by analogy with results in Xenopus, that $\mathrm{Clb}$ degradation would be greatest during mitosis. Thus, $\mathrm{G}_{1}$ cells formed during incubation of clb1,2,3,4 GAL1::CLB1 cells in glucose medium should be devoid of Clb function, because the residual Clb1 synthesized in the previous cell cycle would have been degraded when the cells went through mitosis. Operationally, homozygous diploid $c l b 1,2,3,4$ GAL1::CLB1 cells were incubated in glucose medium for $1 \mathrm{hr}$ (Fig. 7A), and the $\mathrm{G}_{1}$ cells formed during this incubation were isolated by centrifugal elutriation $(\mathrm{Ma}$ terials and methods|. These cells were incubated in glucose medium for another $2 \mathrm{hr}$, during which the DNA content was monitored by flow cytometry (Fig. 7B). Essentially $100 \%$ of the cells budded during this period (Fig. 7C). It is clear from this experiment that despite the presumed complete absence of $\mathrm{Clb}$ proteins, these cells were all able to enter $\mathrm{S}$ phase. However, the cells stopped increasing their DNA content within a short window, about one-third of the way through S phase. The gradual drift of the S-phase peak to increasing fluorescence with time probably reflects increasing autofluorescence as the cells enlarge, al though we cannot rule out the possibility that the cells are slowly and synchronously replicating more of their DNA. This experiment suggests that Clb function becomes critical about one-third of the way through $S$ phase.

\section{Cells without Clb proteins arrest before the hydroxyurea execution point}

We sought to use an alternative method to test the idea of an S-phase role for $\mathrm{Clb}$ proteins. Hydroxyurea, an inhibitor of the enzyme ribonucleotide reductase that maintains DNA precursor pools, arrests yeast cells that have not completed DNA replication in S phase and prevents cell division (Slater 1973). Cells that have completed $\mathrm{S}$ phase divide in the presence of hydroxyurea and become arrested on the subsequent cell cycle. To determine the extent to which they had completed DNA replication, the conditionally lethal $c l b 1,2, c l b 1,2,3$, and $c l b 1,2,3,4$ mutant cells were transferred to glucose medium for $2 \mathrm{hr}$ and then tested for sensitivity to hydroxyurea. Cells were plated on medium containing hydroxyurea, with and without galactose, to allow resumption of $\mathrm{Clb}$ synthesis. The percentages of cells arrested immediately versus those that arrested after one division were tabulated (Table 4; for details, see Materials and methods). For the clb1,2 mutant, $95 \%$ of the budded cells were able to undergo a single division in the presence of hydroxyurea, indicating that they had completed DNA replication during the $2-\mathrm{hr}$ incubation in glucose, consistent with a $\mathrm{G}_{2}$ arrest. For the $c l b 1,2,3$ mutant, however, $26 \%$ of the budded cells were unable to divide, 

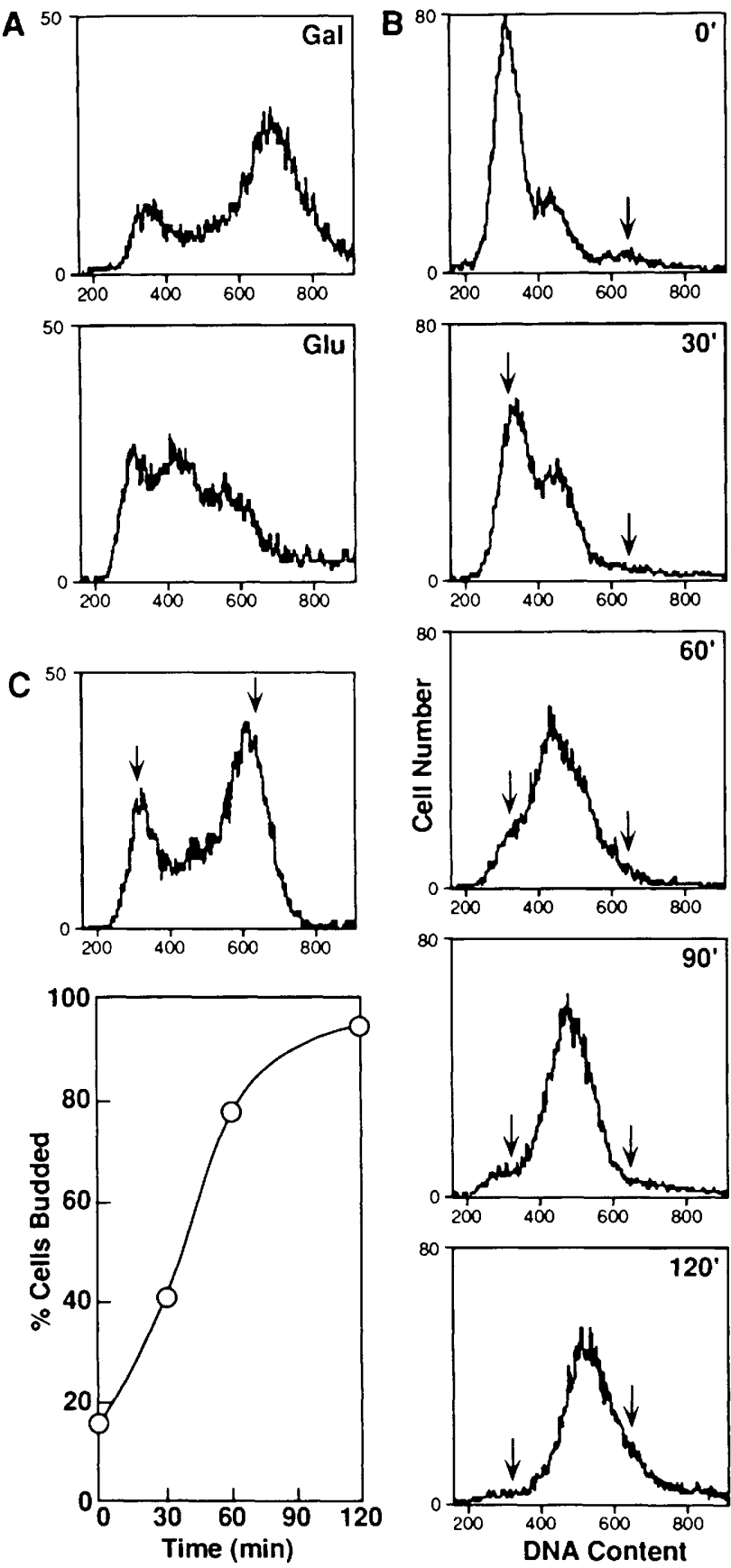

suggesting that they had not yet exited from $S$ phase. The most dramatic outcome was with the clb1,2,3,4 mutant, where $92.5 \%$ of the cells were restrained from dividing by hydroxyurea. Thus, the bulk of these cells have an unreplicated or incompletely replicated DNA content. These data strongly support an S-phase role for Clb proteins.

One potential caveat concerning the result with the clb1,2,3,4 mutant pertains to a loss of viability after prolonged incubation in glucose. We observed that whereas $c l b 1,2$ and $c l b 1,2,3$ mutants recovered rapidly in galactose after $2 \mathrm{hr}$ in glucose, the clb1,2,3,4 mutant recov-
Figure 7. Flow cytometric analysis of synchronized clb1,2,3,4 GAL1::CLB1 cells. (A) Flow cytometry of homozygous diploid clb1,2,3,4 GAL1::CLB1 cells growing on galactose (Gal) or $1 \mathrm{hr}$ after addition of $2 \%$ glucose to terminate $\mathrm{Clbl}$ synthesis (Glu). These cells show three peaks of DNA content corresponding to cells in $G_{1}, G_{2}$, and $S$ phase. $(B)$ Small cells were isolated from the population treated with glucose $(A)$ by centrifugal elutriation. These cells were predominantly in $G_{1}\left(B, O^{\prime}\right)$. The cells were inoculated into medium containing glucose and incubated at $30^{\circ} \mathrm{C}$ for the indicated times before analysis of DNA content (vertical strip, 0-2 hr). Arrows indicate the DNA content of $\mathrm{G}_{1}$ (left) and $\mathrm{G}_{2}$ (right) cells. (C) As a control for the positions of the $G_{1}$ and $G_{2}$ DNA contents for elutriated cells (which are smaller than the starting asynchronous culture), cells were elutriated and returned to galactose medium for $1 \mathrm{hr}(C$, upper panel). The arrows indicating $2 \mathrm{~N}$ and $4 \mathrm{~N}$ positions were derived from this control culture. The lower panel indicates the percent of cells budded for the same cells and time points shown in $B$.

ered much more slowly. In fact $40 \%$ of arrested cells in this experiment were incapable of recovery /these were statistically removed from the analysis). If the remaining $60 \%$ were impaired from recovery by the presence of hydroxyurea, the data for this mutant might be skewed in favor of S-phase arrest. To control for this possibility, we tested whether clb1,2,3,4 cells that had been incubated in glucose medium for $2 \mathrm{hr}$ suffered any additional loss of viability upon exposure to hydroxyurea in galactose medium. Cells were transferred from glucose to galactose/hydroxyurea liquid medium, incubated for $3 \mathrm{hr}$ at $30^{\circ} \mathrm{C}$, and plated on galactose medium without hydroxyurea to assess their viability. The results indicated that the galactose/hydroxyurea incubation had only a small effect on the viability of the cells (data not shown), which would not alter the conclusion that the great majority of $c l b 1,2,3,4$ cells had arrested in S phase.

\section{Morphological analysis of clb mutants}

Microscopic examination of arrested clb1,2,3 cells by Nomarski optics (Fig. 4F), or after staining nuclei with DAPI and spindles with an anti-tubulin antibody (Fig. $8 \mathrm{~A}, \mathrm{~B}\}$, revealed that the arrested cells had large elongated buds, an unlobed nucleus, and a short spindle extending across the nucleus, consistent with arrest in $G_{2}$ (Reed

Table 4. Arrest of Clb-deficient strains in S phase

\begin{tabular}{lccc}
\hline Genotype & $\begin{array}{l}\text { Adjusted } \\
\text { hydroxyurea } \\
\text { sensitive }^{\mathrm{a}}\end{array}$ & $\begin{array}{l}\text { Adjusted } \\
\text { hydroxyurea } \\
\text { insensitive }^{\mathrm{b}}\end{array}$ & $\begin{array}{l}\text { Percent } \\
\text { in S phase }\end{array}$ \\
\hline$c l b 1,2$ & 24 & 463 & 5.0 \\
$c l b 1,2,3$ & 123 & 352 & 26.0 \\
$c l b 1,2,3,4$ & 295 & 24 & 92.5 \\
\hline
\end{tabular}

${ }^{a}$ Total number of cells/600 that did not divide on hydroxyurea minus the number of cells/600 that did not recover after $2 \mathrm{hr}$ in glucose minus the number of cells/600 that were unbudded (prior to S phase) when plated.

${ }^{\mathrm{b}}$ Total number of cells/600 that divided on hydroxurea minus the number of clumps of cells/600 units plated /that would be confused for divided cells). 
and Wittenberg 1990; Ghiara et al. 1991). These data indicate that $C L B$ function is required for the $\mathrm{G}_{2}-$ to $M$-phase transition.

A similar analysis of the conditional $c l b 1,2,3,4$ mutant yielded a strikingly different result. The arrested cells were examined microscopically using Nomarski optics (Fig. 4H), or after staining with DAPI (to visualize nuclei) and with anti-tubulin antibodies (to visualize spindles). As shown in Figure 8,C and D, all cells arrest with elongated buds and an unlobed nucleus (as do the clb1,2,3 cells), but these cells contained no discernible spindle, although fine microtubule fibers were apparent extending from single-microtuble organizing centers. From these observations we conclude that cyclin-B function at some level is required for the assembly or maintenance of an intranuclear spindle. However, we cannot determine whether the spindle pole body has duplicated, an event that normally takes place in late $\mathrm{G}_{1}$ and is controlled at START (Byers and Goetsch 1975).

Because virtually all clb1,2,3,4 cells contained unipolar structures, one might infer that cells already containing spindles and duplicated spindle pole bodies might regress to this state once $\mathrm{Clb}$ function is eliminated. To test this idea directly, clb1,2,3,4 GAL1::CLB1 cells in galactose medium were arrested in $S$ phase by treatment with hydroxyurea (Slater 1973). Under these conditions, cells contain short $\mathrm{G}_{2}$-like intranuclear spindles (Fig. 9A,B). After $3.5 \mathrm{hr}$, cells were resuspended in glucose medium without hydroxyurea to terminate $\mathrm{Clb} 1$ synthe-
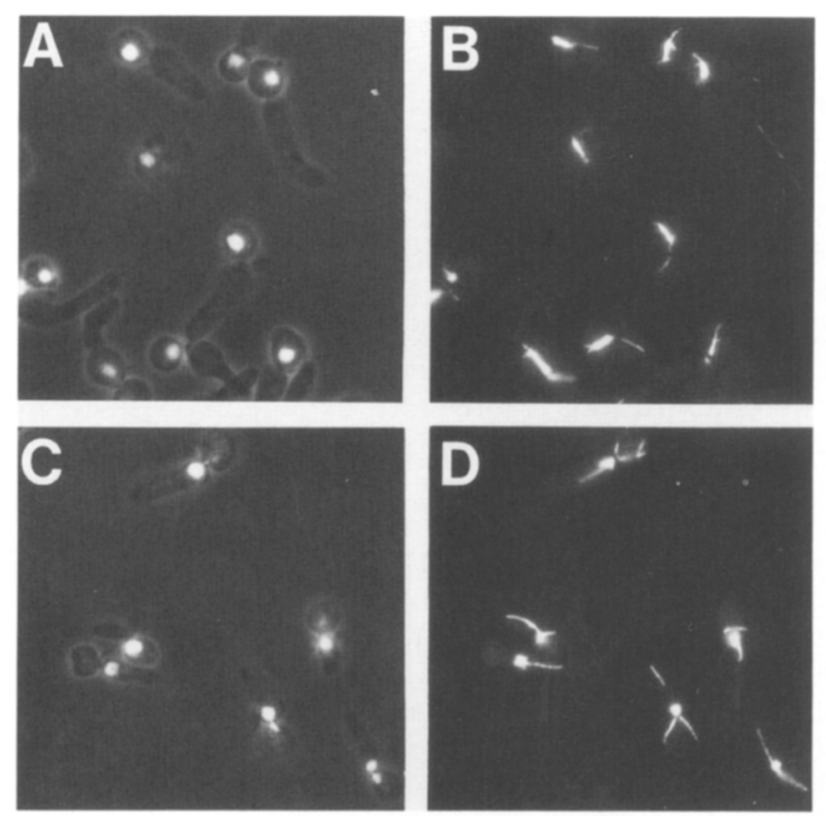

Figure 8. Nuclear and spindle morphology upon loss of $\mathrm{Clb}$ function. $(A, B)$ Homozygous diploid clb1,2,3 GAL1::CLB1 $2 \mathrm{hr}$ after addition of glucose; $(C, D)$ homozygous diploid $c l b 1,2,3,4$ GAL1::CLB1 $2 \mathrm{hr}$ after addition of glucose. $(A, C)$ Staining of nuclear DNA using DAPI and a combination of fluorescent and phase-contrast optics; $|B, D|$ immunofluorescent staining of same field using anti-tubulin antibodies.
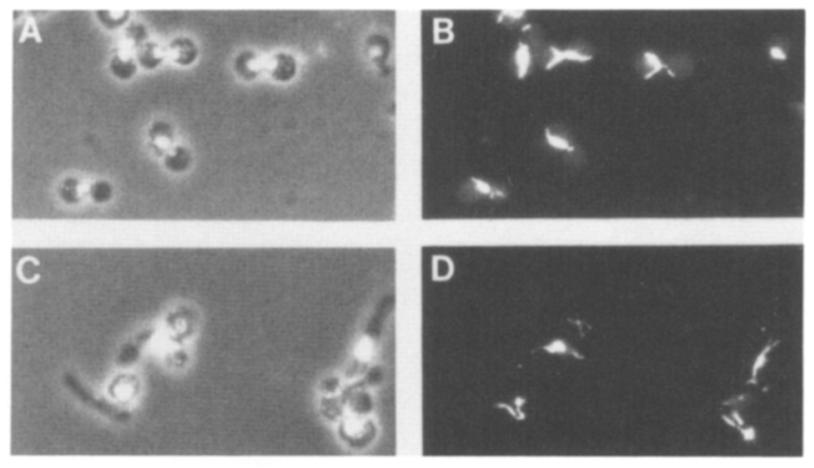

Figure 9. Spindle regression in the absence of Clb function. $(A, B)$ clb1,2,3,4 GAL1::CLB1 in YEP Gal arrested using hydroxyurea $(0.2 \mathrm{M}$ for $3.5 \mathrm{hr}) .(C, D)$ Same cells after termination of $\mathrm{Clbl}$ synthesis by addition of glucose and release from $\mathrm{S}$-phase block by removal of hydroxyurea for $3 \mathrm{hr} .(A, C)$ DAPI staining; $(B, D)$ anti-tubulin staining.

sis and to release the S-phase block. After $3 \mathrm{hr}$, most spindles had regressed to unipolar structures (Fig. 9C,D). Flow cytometric analysis indicated that by this time a significant amount of DNA replication had occurred (data not shown). Thus, a low but significant level of $\mathrm{Clb}$ function is required for the maintanence of an intranuclear spindle, even after the spindle pole bodies have been duplicated.

\section{Discussion}

\section{Clb proteins are essential for mitosis}

B-type cyclins are thought to promote entry into mitosis in a wide variety of organisms through their activation of Cdc28/cdc2 protein kinases. Our results are fully consistent with the idea that $\mathrm{Clb}$ proteins play a similar role in $S$. cerevisiae. clb2 mutants were delayed in the $G_{2}$ phase of the cell cycle, and clb1,2 or clb1,2,3 mutants became arrested in $G_{2}$ (Figs. 5 and 6; Surana et al. 1991). These arrested cells displayed a short intranuclear microtubule spindle characteristic of $\mathrm{G}_{2}$ cells, before the spindle elongation that occurs during mitosis (Fig. 8). In addition, $\mathrm{Clb}$ proteins bind to and activate the histone H1 kinase activity of Cdc28, with maximal activation in mitosis (Ghiara et al. 1991; N. Grandin and S.I. Reed, in prep.). Finally, overexpression of a truncated allele of Clb1 causes an inability to exit from mitosis /Ghiara et al. 1991), suggesting that high $\mathrm{Clb} / \mathrm{Cdc} 28$ kinase activity maintains the mitotic state. Thus, activation of $\mathrm{Clb} /$ Cdc28 kinase at the $G_{2} / M$ transition is very likely to be the trigger for mitosis in S. cerevisiae, as it is in other organisms.

\section{Clb proteins are required for completion of DNA replication}

clb1,2,3,4 mutants underwent arrest with an S-phase DNA content upon loss of the rescuing Clbl (Fig. 6). 
Furthermore, when the arrested cells were returned to growth on media that reinduced $\mathrm{Clb} 1$, it could be seen that they were still sensitive to hydroxyurea (Table 4). Both of these observations suggest that elimination of $\mathrm{Clb}$ function prevents completion of DNA replication. Analysis of synchronized cells lacking $\mathrm{Clb}$ proteins showed that these cells all entered $S$ phase and arrested uniformly after replicating approximately one-third of their nuclear DNA (Fig. 7). This surprising result suggests that $\mathrm{Clb}$ function may not be required for the initiation or elongation phases of DNA replication but, rather, for a distinct function that only becomes essential for DNA replication once a significant part of the genome has been replicated. Possible functions might include initiation of DNA replication at late origins or activation of topoisomerase required to relieve DNA supercoiling generated by replication. In this regard, it is interesting to note that an additional B-type cyclin, Clb5, has recently been identified in $S$. cerevisiae based on its ability to function as a $G_{1}$ cyclin (Epstein and Cross 1992; S.I. Reed, unpubl.). Although the functional relationship of Clb5 to the other Clb proteins is not yet clear, it appears that $\mathrm{Clb} 5$ is required for efficient progression through S phase (Epstein and Cross 1992). It is possible that $\mathrm{Clb5}$ and the other $\mathrm{Clb}$ proteins perform overlapping functions in S phase and that the DNA replication seen in the $c l b 1,2,3,4$ mutant was the result of Clb5 activity. However, different $\mathrm{Clb}$ proteins might perform distinct specialized roles in S phase. Recently, cyclin A has been shown to be required for initiation of, or progression through, $\mathrm{S}$ phase in mammalian somatic cells (Girard et al. 1991; Pagano et al. 1992). Although Clb3, Clb4, and Clb5 do not share strong structural homology with cyclin $\mathrm{A}$, they may perform analogous functions in yeast.

\section{Clb proteins play a role in the assembly} and maintenance of the intranuclear spindle

In $S$. cerevisiae, the spindle pole bodies (the major microtubule-organizing centers in these cells) are duplicated near the $G_{1} / S$ transition (Byers and Goetsch 1975). During $S$ phase, the duplicated spindle pole bodies separate and a short intranuclear spindle forms between them, which is maintained through $G_{2}$ and elongates during mitosis (Byers and Goetsch 1975). Most S. cerevisiae $\mathrm{S}$-phase and $\mathrm{G}_{2}$-arresting $c d c$ mutations confer a terminal phenotype that consists, in part, of a short, thick, intranuclear spindle (Byers and Goetsch 1975; Ghiara et al. 1991). It was therefore rather surprising that the $c l b 1,2,3,4$ mutants deprived of the rescuing Clbl arrested uniformly without a discernible intranuclear spindle (Fig. 8). Moreover, the loss of Clbl in this strain resulted in the disappearance of spindles that had already formed during a hydroxyurea arrest (Fig. 9). Thus, Clb proteins are required for the maintenance and possibly assembly) of the short $G_{2}$ spindle, as well as for the elongation of this spindle during mitosis (see above).

The finding that both DNA replication and spindle assembly were defective in $c l b 1,2,3,4$ mutants raised the possibility that one of these phenotypes was indirectly caused by the other (i.e., that DNA replication was blocked because of the inability to assemble a spindle or that spindle assembly was blocked because of the inability to complete DNA replication). We consider this possibility unlikely because previous studies have shown that DNA replication proceeds unhindered even when microtubule structures are disrupted by nocodazole or $\beta$-tubulin mutations (Huffaker et al. 1988; Jacobs et al. 1988). Similarly, spindle assembly proceeds normally even when DNA replication is blocked by hydroxyurea or various $c d c$ mutations (Byers 1981; Pringle and Hartwell 1981). Thus, we consider it more likely that $\mathrm{Clb}$ proteins directly regulate both DNA replication and spindle assembly.

Another surprising finding was that $c l b 1,2,3,4 \mathrm{mu}-$ tants suffered a dramatic loss of viability $3-4 \mathrm{hr}$ after withdrawal of the rescuing Clbl. In contrast, $c l b 1,2,3$ mutants did not show a significant loss of viability during this period. This difference suggests that the loss of viability was a result of the defects observed uniquely with the $c l b 1,2,3,4$ mutant, namely impaired DNA replication and spindle assembly. Possibly, the unipolar microtubule structure of this mutant corresponds to an irreversible state, blocking further cell cycle progress. Alternatively, the defect in DNA replication may lead to lesions that cannot be repaired efficiently.

\section{Which Clb protein does what?}

The genetic data reported here demonstrate that $\mathrm{Clb}$ proteins perform several critical functions during the cell cycle (above), with $\mathrm{Clb} 2$ making the strongest contribution to these functions and Clb4 the weakest. Our observations with different lethal $c l b$ mutant combinations suggest that a low level of $\mathrm{Clb}$ function is required for DNA replication and a high level of Clb function is required for chromosome segregation. Similarly, a low level of $\mathrm{Clb}$ function suffices for assembly and maintenance of a short interphase spindle while a higher level is required for spindle elongation in mitosis. All four $\mathrm{Clb}$ proteins are able to provide the DNA replication and spindle assembly functions, and at least $\mathrm{Clbl}, \mathrm{Clb} 2$, and Clb3 can contribute to the mitotic functions. However, these data do not reveal whether different $\mathrm{Clb}$ proteins are normally responsible for the separate functions (but can substitute for each other when necessary) or whether all $\mathrm{Clb}$ proteins participate redundantly in all functions.

Although not revealed by the genetic experiments, there are strong reasons to believe that $\mathrm{Clb}$ proteins fall into two functional classes, with $\mathrm{Clb} 3$ and $\mathrm{Clb} 4$ performing the S-phase and early spindle assembly roles and $\mathrm{Clb} 1$ and $\mathrm{Clb} 2$ performing the mitotic roles. First, sequence analysis shows that $\mathrm{Clb} 3 / \mathrm{Clb} 4$ and $\mathrm{Clbl} / \mathrm{Clb} 2$ form pairs that are related much more closely to each other than they are to members of the other pair. Furthermore, Clb3 and Clb4 are related most closely to the $S$. pombe cyclin cig1 (Fig. 2), which appears to play a role in $G_{1}$ or $S$ phase (Bueno et al. 1991), whereas Clb1 and Clb2 show highest homology to the $S$. pombe cyclin cdc13 involved in the initiation of mitosis. Second, 
mRNAs for $\mathrm{Clb} 3$ and $\mathrm{Clb} 4$ are expressed [and corresponding kinases are activated (N. Grandin and S.I. Reed, in prep.|) earlier in the cell cycle than those for $\mathrm{Clbl}$ and Clb2 (Fig. 3). Thus, we propose that in the normal cell cycle $\mathrm{Clb} 3$ and $\mathrm{Clb} 4$ function in $\mathrm{S}$ phase to promote DNA replication and spindle assembly, while Clbl and Clb2 (possibly aided by $\mathrm{Clb} 3$ and $\mathrm{Clb} 4$ ) are mainly responsible for mitotic induction. This model, however, requires a certain plasticity of $\mathrm{Clb}$ function, such that $\mathrm{Clbl}$ and/or $\mathrm{Clb} 2$ can fulfill early cell cycle functions if Clb3 and Clb4 are not present.

\section{Substrates for the Clb/Cdc28 protein kinase}

Given the broad range of precedents for cyclin B in other eukaryotic cells and our previous results with $\mathrm{Clbl}$ /Ghiara et al. 1991), it is very likely that Clb proteins exert their effects through activation of the $\mathrm{Cdc} 28$ protein kinase and consequent phosphorylation of appropriate substrates. The $\mathrm{Clb}$ functions identified in this report provide clues to the possible identity of these substrates. The DNA replication function may reflect a need to phosphorylate proteins that form part of the replication complexes, whereas spindle-associated motor proteins are attractive candidates for substrates involved in spindle elongation. The role uncovered here in spindle maintenance might also reflect a requirement to phosphorylate kinesin-like motors shown recently to be crucial for spindle pole body separation (Hoyt et al. 1992; Roof et al. 1992). Alternatively, perhaps nucleation of microtubules on the nuclear side of the spindle pole body requires phosphorylation of spindle pole body components by the $\mathrm{Clb} / \mathrm{Cdc} 28$ kinase. Consistent with this idea, the collapse of already assembled spindles in the absence of $\mathrm{Clb}$ function is reminiscent of the return of spindle pole bodies to a side-by-side configuration in cells treated with microtubule-depolymerizing drugs such as benomyl and nocodazole (Jacobs et al. 1988).

\section{Materials and methods}

\section{Cloning the CLB2, CLB3, and CLB4 genes}

The $S$. cerevisiae cyclin-B homolog CLB1 (SCB1) was isolated by using PCR and degenerate oligonucleotides designed to the AA/S)KYEE and AKYL(F)M(VI)E motifs (Ghiara et al. 1991). To isolate other cyclin-B homologs from $S$. cerevisiae using the PCR technique (Saiki et al. 1988) the following degenerate oligonucleotides were used: $5^{\prime}$ primer, 5'-CCGGATCCMRNYTNCARYTNGTNGG-3' corresponding to the amino acid sequence KLQLVG; $3^{\prime}$ primer, 5'-CGAATTCYTCNAYNARRTAYTTNGC-3' corresponding to the amino acid sequence AKYL(F)M(VI)E $\quad(\mathrm{Y}=\mathrm{C}+\mathrm{T}, \quad \mathrm{R}=\mathrm{A}+\mathrm{G}, \quad \mathrm{M}=\mathrm{C}+\mathrm{A}$, $\mathrm{N}=\mathrm{A}+\mathrm{G}+\mathrm{C}+\mathrm{T})$. The BamHI and EcoRI restriction sites used for cloning are underlined. The PCR products were digested with $B a m H I$ and $E c o R I$ restriction enzymes, gel purified, and cloned into the BamHI and EcoRI sites of pT7T319U (Pharmacia).

Using PCR and the KLQLVG and AKYL(F)M(VI)E primers, a second cyclin-B homolog was isolated from $S$. cerevisiae. The derived amino acid sequence of this clone was identical to the partial amino acid sequence of the CLB3 gene, as presented by
Surana et al. (1991). To isolate the complete genomic clone, a radiolabeled probe made from the PCR clone of $C L B 3$ was used to screen a $S$. cerevisiae genomic library in the vector $\lambda$ Dash (obtained from Merl Hoekstra, Salk Institute, San Diego, CA). DNA sequence analysis revealed an open reading frame of 1278 bp, predicted to encode a protein of 426 amino acids (Fig. 1A).

The $C L B 2$ gene was obtained by screening the $\lambda$ Dash $S$. cerevisiae genomic library under low stringency conditions (as described below) with a $C L B 1$ probe (0.5-kb EcoRV fragment) containing the cyclin box region. The sequence identified had several discrepancies relative to that reported by Surana et al. (1991): At position - 108, they have TATAACCCC, whereas we have TATAAAAAC, which fits the consensus sequence for a TATA box; and at position 1510, they have TGA, whereas we have TAA.

The $C L B 4$ gene was isolated by screening the $\lambda$ Dash $S$. cerevisiae genomic library under low stringency conditions (as described below) with a $C L B 3$ probe specific for the cyclin box (the $C L B 3$ PCR clone). The derived amino acid sequence of this gene was similar to the partial amino acid sequence of CLB4 presented by Surana et al. (1991).

Radiolabeled probes were made using the random primer DNA labeling kit (Boehringer Mannheim) according to the manufacturer's instructions. For Southern blot analysis, DNA was transferred to nitrocellulose filters (Schleicher \& Schuell).

\section{Construction of clb null mutations}

The CLB2 null allele (clb2::LEU2) was constructed by utilizing a 2.8-kb EcoRI subclone derived from a phage clone of $C L B 2$. This clone enabled the $0.38-\mathrm{kb} E c o \mathrm{RV}-B g I I I$ fragment from the cyclin box region to be replaced with a $2.5 \mathrm{~kb}$ PvuII-BamHI fragment containing $L E U 2$ (derived from a clone of $L E U 2$ in pUC19) The construct was then excised with Nsil and used to transform BF264-15DUa. Transformants were selected on minimal plates supplemented with amino acids but lacking leucine.

The $C L B 3$ null allele (clb3::TRP1) was constructed as follows. A 1.5-kb BgIII-HincII fragment containing the TRP1 gene (from the plasmid YRp7) was used to replace the 0.58-kb BgIII-EcoRV fragment containing the cyclin box region of $C L B 3$. The target for insertion was a $2.7-\mathrm{kb}$ ClaI-Sall clone of CLB3 in pT7T3 19U. The resulting disruption construct was then excised with SalI and ClaI and used to transform BF264-15DUa. Transformants were selected on minimal plates supplemented with amino acids but lacking tryptophan.

The CLB4 null allele (clb4::HIS2) was constructed by the replacement of a $1.8 \mathrm{-kb} E c o \mathrm{RV}-N$ siI fragment containing the CLB4 gene with a $1.9-\mathrm{kb}$ PstI-EcoRI fragment containing HIS2 (derived from a clone of HIS2 in pUC118). This insertion was carried out in the 3.8-kb EcoRI clone of CLB4. The construct was excised with AseI and EcoRI and used to transform YS102. Transformants were selected on minimal plates supplemented with amino acids but lacking histidine.

In all cases, transformants were screened for the gene disruption by Southern blot analysis of genomic DNA.

Yeast strains, genetic procedures, media, and growth conditions

All yeast strains used in this study were derivatives of BF26415DU: MATa ade1 his2 leu2-3,112 trp1-1 a ura3Dns (Richardson et al. 1989). The relevant genotypes of strains used in this study are shown in Table 5.

Standard genetic procedures for yeast were used (Sherman et al. 1982). Yeast transformations were carried out by the alkali 
Table 5. Strain list

\begin{tabular}{|c|c|}
\hline Strain & Relevant genotype \\
\hline YH134 & MATa $c l b 1:: U R A 3$ \\
\hline YH135 & MATa $c l b 2:: L E U 2$ \\
\hline YS101 & MATa $c l b 3:: T R P 1$ \\
\hline YS102 & MATa $c l b 1:: U R A 3$ clb3::TRP1 \\
\hline YS104 & MATa $c l b 1:: U R A 3$ clb3::TRP1 clb4::HIS2 \\
\hline YS105 & MATa GAL1::CLB1(LEU2) clb1::URA3 clb3::TRP1 clb4::HIS2 \\
\hline YS106 & MAT $\alpha$ clb2::LEU2 \\
\hline YS107 & MATa GAL1::CLB1(LEU2) clb1::URA3 clb2::LEU2 clb3::TRP1 \\
\hline YS108 & MATa GAL1::CLB1(LEU2) clb1::URA3 clb2::LEU2 clb3::TRP1 clb4::HIS2 \\
\hline YS112 & MATa $c l b 4:: H I S 2$ \\
\hline YS109 & MATa GAL1::CLB1(LEU2) clb1::URA3 clb2::LEU2 \\
\hline YS114 & MATa $c l b 1:: U R A 3$ clb4::HIS2 \\
\hline YS1 15 & MATa $c l b 2:: L E U 2$ clb4::HIS2 \\
\hline YS118 & MATa $c l b 3:: T R P 1$ clb4::HIS2 \\
\hline YS201 & $M A T \mathbf{a} / \alpha$ clb1::URA3/CLB1 clb3::TRP1/CLB3 \\
\hline YS202 & $M A T \mathbf{a} / \alpha$ clb1::URA3/CLB1 clb3::TRP1/CLB3 clb2::LEU2/CLB2 \\
\hline YS203 & $M A T \mathrm{a} / \alpha$ GAL1::CLB1(LEU2) clb1::URA3/CLB1 clb3::TRP1/CLB3 clb2::LEU2/CLB2 clb4::HIS2/CLB4 \\
\hline DLY005 & $\mathrm{MATa} / \alpha$ \\
\hline DLY373 & $M A T \mathbf{a} / \alpha$ clb2::LEU2/clb2::LEU2 \\
\hline DLY378 & MATa/ $\alpha$ clb3::TRP1/clb3::TRP1 clb4::HIS2/clb4::HIS2 \\
\hline DLY379 & MATa/ $\alpha$ clb1::URA3/clb1::URA3 clb3::TRP1/clb3::TRP1 clb4::HIS2/clb4::HIS2 \\
\hline DLY380 & MATa/ $\alpha$ GAL1::CLB1(LEU2) clb1::URA3/clb1::URA3 clb2::LEU2/clb2::LEU2 \\
\hline DLY382 & MATa/ $\alpha$ GAL1::CLB1(LEU2) clb1::URA3/clb1::URA3 clb2::LEU2/clb2::LEU2 clb3::TRP1/clb3::TRP1 \\
\hline DLY384 & $\begin{array}{l}\text { MATa/ } \alpha \text { GAL1::CLB1(LEU2) clb1::URA3/clb1::URA3 clb2::LEU2/clb2::LEU2 clb3::TRP1/clb3::TRP1 } \\
\quad \text { clb4::HIS2/clb4::HIS2 }\end{array}$ \\
\hline
\end{tabular}

cation method (Ito et al. 1983). Genomic sequence replacements were performed as described by Rothstein (1983).

Yeast cultures were grown at $30^{\circ} \mathrm{C}$ in YEP $\{1 \%$ yeast extract, $2 \%$ Bacto-peptone, $0.005 \%$ adenine, $0.005 \%$ uracil) supplemented with glucose $(2 \%)$ or galactose $(2 \%)$. Conditional Clbl synthesis was terminated (GAL1:CLB1 strains) by adding $50 \%$ glucose to cultures growing in YEP/galactose medium to a final concentration of $2 \%$. Cultures were arrested in S phase (Fig. 8 ) by growth in YEP/galactose supplemented with $0.2 \mathrm{M}$ hydroxyurea for $3.5 \mathrm{hr}$ and released from the block by resuspension in YEP/glucose.

Hydroxyurea execution point experiments (Table 4) were performed by growing GAL1::CLB1 clb1,2, GAL1::CLB1 clb1,2,3, and $G A L 1:: C L B 1$ clb1,2,3,4 mutant strains in glucose-supplemented medium for $2 \mathrm{hr}$, after which cells were subjected to a short pulse of sonic disruption and plated on each of three types of solid medium: (1) minimal synthetic medium containing $2 \%$ glucose, (2) YEP/galactose, and (3) YEP/galactose supplemented with $0.4 \mathrm{M}$ hydroxyurea. The first plate, which was immediately stored at $4^{\circ} \mathrm{C}$, served as a record of the composition of the plated cell population. The second plate served as viability control for the nutritional shift from glucose to galactose and was maintained at $30^{\circ} \mathrm{C}$ for $12 \mathrm{hr}$. The third plate, kept at $30^{\circ} \mathrm{C}$ for $20 \mathrm{hr}$, was used to determine whether individual cells could undergo a round of division in the presence of the replication inhibitor hydroxyurea. Cells were observed directly on the agar surface, using a low power objective and a stage modified to accommodate $100-\mathrm{mm}$ petri dishes. The plating control (minimal plate) was scored by assigning cells to three catagories: unbudded cells, singly budded cells, and units composed of multiple buds or cells. The viability control was scored by assigning cells to two catagories: single cells and microcolonies. Single cells were assumed to be inviable. The experimental plate was scored by assigning cells to two catagories: undivided (singly budded) cells and divided (two side-by-side budded) cells. To calculate the percentage of S-phase (hydroxyurea sensitive) cells, the number of inviable cells (viability control) and unbudded cells (plating control) was subtracted from the number of cells that did not divide on hydroxyurea to give an adjusted hydroxyurea-sensitive cell number. The number of multiple cells (plating control) was subtracted from the number of cells that divided on hydroxyurea to give an adjusted hydroxyurea-insensitive cell number. The percentage of S-phase cells was then calculated by dividing the adjusted hydroxyurea-sensitive cell number by the sum of the adjusted hydroxyurea-sensitive and -insensitive cell numbers. The calculations were based on scoring 600 independent structures (cells, pairs of cells, or microcolonies) on each plate.

Photomicroscopy, immunofluorescence staining, cell counting, flow cytometry, and cell synchrony

Yeast cells were photographed live, using differential interference contrast (Nomarski) optics with a $100 \times$ objective. Fluorescent photomicroscopy on fixed and stained cells was performed using a Zeiss Axiophot photomicroscope with a $100 \times$ objective. DAPI and anti-tubulin antibody staining was performed as described by Ghiara et al. (1991).

Cell numbers and budding percentages were determined using a hemacytometer and a Leitz SM-Lux phase-contrast microscope with a $40 \times$ objective.

Cell cultures were analyzed fór DNA content using flow cytometry by the method of Hutter and Eipel (1979). Yeast cells were fixed in $70 \%$ ethanol, stained with propidium iodide, and analyzed for fluorescence using a Becton-Dickinson FACScan analyzer (Lew et al. 1992).

Cell synchrony using mating pheromone was as described by 
Ghiara et al. (1991). Centrifugal elutriation was performed as described by Lew et al. (1992).

\section{Acknowledgments}

We are very grateful to Pat O'Farrell and Rob Saint for supplying laboratory space, equipment, and materials to H.E.R. for part of this work. Thanks go to C. Epstein and F. Cross for communication of results before publication. We also thank Dalia Resnitzky for help with various aspects of this work and Nathalie Grandin for critical reading of this manuscript. H.E.R was supported for part of this work by an Australian Research Council QEII fellowship. D.J.L. was supported by a Damon RunyonWalter Winchell Cancer Research Fund Fellowship (DRG1078). This work was supported by U.S. Public Health Service grant GM38328 to S.I.R.

The publication costs of this article were defrayed in part by payment of page charges. This article must therefore be hereby marked "advertisement" in accordance with 18 USC section 1734 solely to indicate this fact.

\section{Note added in proof}

Sequence data described in this paper have been submitted to the GenBank data library.

\section{References}

Booher, R. and D. Beach. 1987. Interaction between $c d c 13^{+}$and $c d c 2^{+}$in the control of mitosis in fission yeast; dissociation of the $\mathrm{G} 1$ and $\mathrm{G} 2$ roles of the $c d c 2^{+}$protein kinase. EMBO I. 6: 3441-3447.

- 1988. Involvement of $\mathrm{cdcl}^{+}$in mitotic control in Schizosaccharomyces pombe: Possible interaction of the gene product with microtubeules. EMBO J. 7: 2321-2327.

Bueno, A., H. Richardson, S.I. Reed, and P. Russell. 1991. A fission yeast B-type cyclin functioning early in the cell cycle. Cell 66: 149-159.

Byers, B. 1981. Cytology of the yeast life cycle. In The molecular biology of the yeast Saccharomyces: Life cycle and inheritance (ed. J.N. Strathern, E.W. Jones, and J.R. Broach), pp. 59-97. Cold Spring Harbor Laboratory, Cold Spring Harbor, New York

Byers, B. and L. Goetsch. 1975. Behavior of spindles and spindle plaques in the cell cycle and conjugation of Saccharomyces cerevisiae. J. Bacteriol. 124: 511-523.

Cross, F. 1988. DAF1, a mutant gene affecting size control, pheromone arrest, and cell cycle kinetics of Saccharomyces cerevisiae. Mol. Cell. Biol. 8: 4675-4684.

- 1990. Cell cycle arrest caused by $C L N$ gene deficiency in Saccharomyces cerevisiae resembles START-arrest and is independent of the mating-pheromone signalling pathway. Mol. Cell. Biol. 10: 6482-6490.

Cross, F., J. Roberts, and H. Weintraub. 1989. Simple and complex cell cycles. Annu. Rev. Cell Biol. 5: 341-395.

Elledge, S.J. and M.R. Spottswood. 1991. A new human p34 protein kinase, CDK2, identified by complementation of a cdc28 mutation in Saccharomyces cerevisiae, is a homolog of Xenopus Eg1. EMBO I. 10: 2653-2659.

Epstein, C.B. and F.R. Cross. 1992. CLB5: A novel B cyclin from budding yeast with a role in S phase. Genes \& Dev. 6: 16951706.

Evans, T., E.T. Rosenthal, J. Youngblom, D. Distel, and T. Hunt. 1983. Cyclin: A protein specified by maternal mRNA in sea urchin eggs that is destroyed at each cleavage division. Cell
33: 389-396.

Fang, F. and J.W. Newport. 1991. Evidence that the G1-S and G2-M transitions are controlled by different cdc2 proteins in higher eukaryotes. Cell 66: 731-742.

Forsburg, S.L. and P. Nurse. 1991. Identification of a G1-type cyclin $\mathrm{puc}^{+}$in the fission yeast Schizosaccharomyces pombe. Nature 351: 245-248.

Ghiara, J.B., H.E. Richardson, K. Sugimoto, M. Henze, D.J. Lew, C. Wittenberg, and S.I. Reed. 1991. A cyclin B homolog in S. cerevisiae: Chronic activation of the $\mathrm{Cdc} 28$ protein kinase by cyclin prevents exit from mitosis. Cell 65: 163-174.

Girard, F., U. Strausfeld, A. Fernandez, and N.J.C. Lamb. 1991. Cyclin $\mathrm{A}$ is required for the onset of DNA replication in mammalian fibroblasts. Cell 67: 1169-1179.

Glotzer, M., A.W. Murray, and M.W. Kirschner. 1991. Cyclin is degraded by the ubiquitin pathway. Nature 349: 132-138.

Hadwiger, J.A., C. Wittenberg, H.E. Richardson, M. de Barros Lopes, and S.I. Reed. 1989). A novel family of cyclin homologs that control Gl in yeast. Proc. Natl. Acad. Sci. 86: 6255-6259.

Hagan, I.M., J. Hayles, and P. Nurse. 1988. Cloning and sequencing of the cyclin related $c d c 13^{+}$gene and a cytological study of its role in fission yeast mitosis. J. Cell Sci. 91: 587-595.

Hartwell, L.H., J. Culotti, J.R. Pringle, and B.J. Reid. 1974. Genetic control of the cell division cycle in yeast. Science 183: 46-51.

Hoyt, M.A., L. He, K.K. Loo, and W.S. Saunders. 1992. Two Saccharomyces cerevisiae kinesin-related gene products required for mitotic spindle assembly. J. Cell Biol. 118: 109120.

Huffaker, T.C., J.H. Thomas, and D. Botstein. 1988. Diverse effects of $\beta$-tubulin mutations on microtubule formation and function. J. Cell Biol. 106: 1997-2010.

Hunt, T. 1989. Maturation promoting factor, cyclin and the control of M-phase. Curr. Opin. Cell Biol. 1: 268-274.

Hunt, T., F.C. Luca, and J.V. Ruderman. 1992. The requirements for protein synthesis and degradation, and the control of destruction of cyclins A and B in the meiotic and mitotic cell cycles of the clam embryo. I. Cell Biol. 116: 707-724.

Hutter, K.-J. and H.E. Eipel. 1979. DNA determination of yeast by flow cytometry. J. Gen. Microbiol. 113: 369-375.

Ito, H., Y. Fukuda, K. Murata, and A. Kimura. 1983. Transformation of intact yeast cells treated with alkali cations. $J$. Bacteriol. 153: 163-168.

Jacobs, C.W., A.E.M. Adams, P.J. Szaniszlo, and J.R. Pringle. 1988. Functions of microtubules in the Saccharomyces cerevisiae cell cycle. J. Cell Biol. 107: 1409-1426.

Lehner, C.F. and P.H. O'Farrell. 1990. The roles of Drosophila cyclins A and B in mitotic control. Cell 61: 535-547.

Lew, D.J. and S.I. Reed. 1992. A proliferation of cyclins. Trends Cell Biol. 2: 77-81.

Lew, D.J., V. Dulic, and S.I. Reed. 1991. Isolation of three novel human cyclins by rescue of $\mathrm{Gl}$ cyclin $(\mathrm{Cln})$ function in yeast. Cell 66: 1197-1206.

Lew, D.J., N.M. Marini, and S.I. Reed. 1992. Different Gl cyclins control the timing of cell cycle commitment in mother and daughter cells of the budding yeast $S$. cerevisiae. Cell 69: 317-327.

Lewin, B. 1990. Driving the cell cycle: $M$ phase kinase, its partners, and substrates. Cell 61: 535-547.

Maller, J. 1991. Mitotic control. Curr. Opin. Cell Biol. 3: 269275.

Minshull, J., J.J. Blow, and T. Hunt. 1989. Translation of cyclin mRNA is necessary for extracts of activated Xenopus eggs to enter mitosis. Cell 56: 947-956.

Minshull, J., R. Golsteyn, C.S. Hill, and T. Hunt. 1990. The A- 
and B-type cyclin-associated $c d c 2$ kinases in Xenopus turn on and off at different times in the cell cycle. EMBO $\%$. 9: $2865-2875$.

Murray, A.W. and M.W. Kirschner. 1989a. Dominoes and clocks: The union of two views of the cell cycle. Science 246: 614-621.

-1989b. Cyclin synthesis drives the early embryonic cell cycle. Nature 339: 275-280.

Murray, A.W., M.J. Solomon, and M.W. Kirschner. 1989. The role of cyclin synthesis in the control of maturation promoting factor activity. Nature 339: 280-286.

Nash, R., G. Tokiwa, S. Anand, K. Erickson, and A.B. Futcher. 1988. The $\mathrm{WHI}^{+}$gene of Saccharomyces cerevisiae tethers cell division to cell size and is a cyclin homolog. EMBO $/$. 7: 4335-4346.

Nasmyth, K., A. Seddon, and G. Ammerer. 1987. Cell cycle regulation of $S W I 5$ is required for mother-cell-specific $H O$ transcription in yeast. Cell 49: 549-558.

Needleman, S.B. and C.D. Wunsch. 1970. A general method applicable to the search for similarities in the amino acid sequence of two proteins. I. Mol. Biol. 48: 443-453.

Ninomiya-Tsuji, J., S. Nomoto, H. Yasuda, S.I. Reed, and K. Matsumoto. 1991. Cloning of a human cDNA encoding a CDC2-related kinase by complementation of a budding yeast $c d c 28$ mutation. Proc. Natl. Acad. Sci. 88: 9006-9010.

Nurse, P. 1990. Universal control mechanism regulating onset of M-phase. Nature 344: 503-508.

Nurse, P. and Y. Bissett. 1981. Gene required in G1 for commitment to cell cycle and in G2 for control of mitosis in fission yeast. Nature 292: 448-460.

Pagano, M., R. Pepperkok, F. Verde, W. Ansorje, and G. Draetta. 1992. Cyclin A is required at two points in the human cell cycle. EMBO J. 11: 961-971.

Paris, J., R. Le Guellec, A. Couturier, K. Le Guellec, F. Omilli, J. Camonis, S. MacNeill, and M. Philippe. 1991. Cloning by differential screening of a Xenopus cDNA coding for a protein highly homologous to cdc2. Proc Natl. Acad. Sci. 88: 1039-1043.

Piggott, J.R., R. Rai, and B.L.A. Carter. 1982. A bifunctional gene product involved in two phases of the yeast cell cycle. $\mathrm{Na}$ ture 298: 391-393.

Pines, J. and T. Hunter. 1989. Isolation of a human cyclin cDNA: Evidence for cyclin mRNA and protein regulation in the cell cycle and for interaction with $\mathrm{p} 34^{\text {cdc2 }}$. Cell 58: 833846.

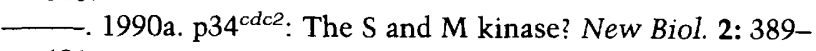
401.

1990b. Human cyclin A is adenovirus E1A-associated protein p60 and behaves differently from cyclin B. Nature 346: $760-763$.

Pringle, J.R. and L.H. Hartwell. 1981. The Saccharomyces cerevisiae cell cycle. In The molecular biology of the yeast Saccharomyces: Life cycle and inheritance (ed. J.N. Strathern, E.W. Jones, and J.R. Broach), pp. 97-142. Cold Spring Harbor Laboratory, Cold Spring Harbor, New York.

Reed, S.I. 1991. Gl-specific cyclins: In search of an S-phasepromoting factor. Trends Genet. 7: 95-99.

Reed, S.I. and C. Wittenberg. 1990. A mitotic role for the Cdc28 protein kinase of S. cerevisiae. Proc Natl. Acad. Sci. 87: 5697-5701.

Richardson, H.E., C. Wittenberg, F. Cross, and S.I. Reed. 1989. An essential G1 function for cyclin-like proteins in yeast. Cell 59: 1127-1133.

Riabowol, K., G. Draetta, L. Brizuela, D. Vandre, and D. Beach. 1989. The cdc2 kinase is a nuclear protein that is essential for mitosis in mammalian cells. Cell 57: 393-401.
Roof, D.M., P.B. Meluh, and M.D. Rose. 1992. Kinesin-related proteins required for assembly of the mitotic spindle. J. Cell Biol. 118: 95-108.

Rothstein, R.J. 1983. One-step gene disruption in yeast. Methods Enzymol. 101: 202-211.

Saiki, R.K., D.H. Gelfand, S. Stoffel, S.J. Scharf, R. Higuchi, G.T. Horn, K.B. Mullis, and H.A. Erlich. 1988. Primer-directed enzymatic amplification of DNA with a thermostable DNA polymerase. Science 239: 487-491.

Sherman, F., G. Fink, and J.B. Hicks. 1982. Methods in yeast genetics. Cold Spring Harbor Laboratory, Cold Spring Harbor, New York.

Slater, M.L. 1973. Effect of reversible inhibition of deoxyribonucleic acid synthesis on the yeast cell cycle. J. Bacteriol. 113: 263-270.

Sudbery, P., A.R. Goodey, and B.L.A. Carter. 1980. Genes which control cell proliferation in the yeast Saccharomyces cerevisiae. Nature 288: 401-404.

Surana, U., H. Robitsch, C. Price, T. Schuster, I. Fitch, A.B. Futcher, and K. Nasmyth. 1991. The role of CDC28 and cyclins during mitosis in the budding yeast $S$. cerevisiae. Cell 65: 145-161.

Swenson, K.I., K.M. Farrell, and J.V. Ruderman. 1986. The clam embryo protein cyclin A induces entry into $M$-phase and the resumption of meiosis in Xenopus oocytes. Cell 47: 861870.

Th'ng, J.P.H., P.S. Wright, J. Hamaguchi, M.G. Lee, C.J. Norbury, P. Nurse, E.M. Bradbury. 1990. The FT210 cell line is a mouse $\mathrm{G} 2$ phase mutant with a temperature-sensitive CDC2 gene product. Cell 63: 313-324.

Tsai, L.-H., E. Harlow, and M. Meyerson. 1991. Isolation of the human $c d k 2$ gene that encodes the cyclin A- and adenovirus E1A-associated p33 kinase. Nature 353: 174-177.

Wang, J., X. Chenivesse, B. Henglein, and C. Brechot. 1990. Hepatitis B virus integration in a cyclin A gene in a hepatocellular carcinoma. Nature 343: 555-557.

Wittenberg, C., K. Sugimoto, and S.I. Reed. 1990. G1-specific cyclins of $S$. cerevisiae: Cell cycle periodicity, regulation by mating pheromone, and association with the $\mathrm{p} 34^{C D C 28}$ protein kinase. Cell 62: 225-237.

Xiong, Y. and D. Beach. 1991. Population explosion in the cyclin family. Curr. Biol. 1: 362-364. 


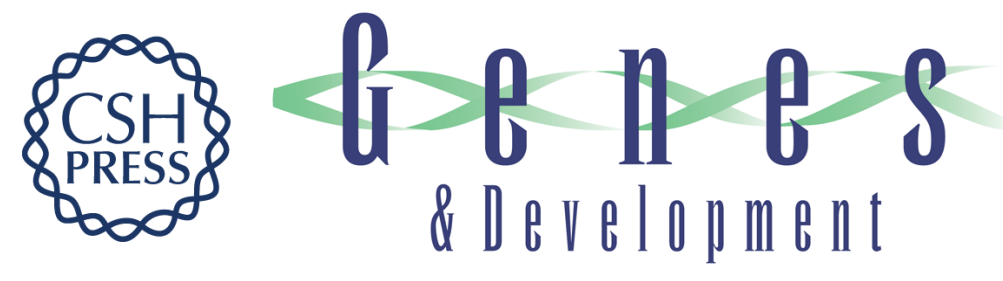

\section{Cyclin-B homologs in Saccharomyces cerevisiae function in S phase and in G2.}

H Richardson, D J Lew, M Henze, et al.

Genes Dev. 1992, 6:

Access the most recent version at doi:10.1101/gad.6.11.2021

References This article cites 64 articles, 19 of which can be accessed free at: http://genesdev.cshlp.org/content/6/11/2021.full.html\#ref-list-1

License

Email Alerting

Receive free email alerts when new articles cite this article - sign up in the box at the top Service right corner of the article or click here.

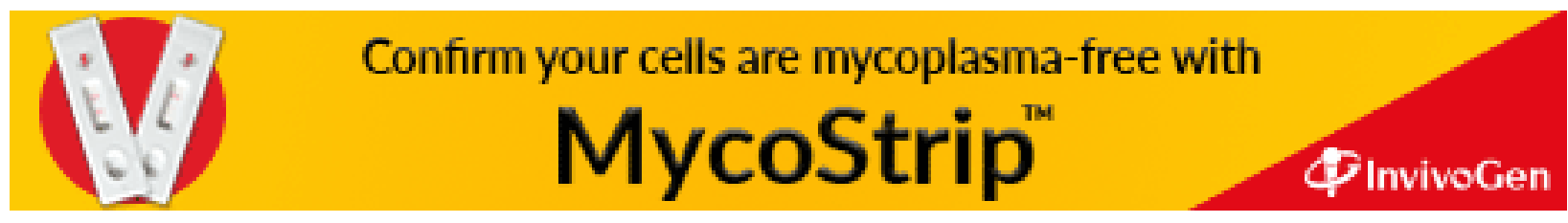

